\title{
Novel Modular Rhodopsins from Green Algae Hold Great Potential for Cellular Optogenetic Modulation Across the Biological Model Systems
}

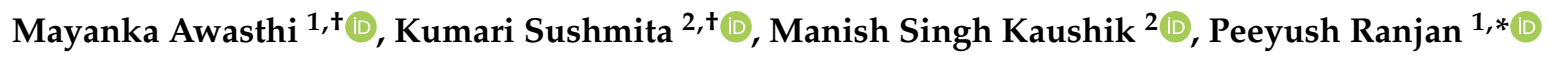 \\ and Suneel Kateriya ${ }^{2, *(1)}$ \\ 1 Department of Cell Biology and Molecular Genetics, University of Maryland, College Park, MD 20742, USA; \\ awasthi9@umd.edu \\ 2 Laboratory of Optobiology, School of Biotechnology, Jawaharlal Nehru University, New Delhi 110067, India; \\ sushmi59_sbt@jnu.ac.in (K.S.); manish13587@gmail.com (M.S.K.) \\ * Correspondence: rpeeyush@umd.edu (P.R.); skateriya@jnu.ac.in (S.K.) \\ + Equally contributed.
}

Received: 3 September 2020; Accepted: 19 October 2020; Published: 28 October 2020

check for updates

\begin{abstract}
Light-gated ion channel and ion pump rhodopsins are widely used as optogenetic tools and these can control the electrically excitable cells as (1) they are a single-component system i.e., their light sensing and ion-conducting functions are encoded by the 7-transmembrane domains and, (2) they show fast kinetics with small dark-thermal recovery time. In cellular signaling, a signal receptor, modulator, and the effector components are involved in attaining synchronous regulation of signaling. Optical modulation of the multicomponent network requires either receptor to effector encoded in a single ORF or direct modulation of the effector domain through bypassing all upstream players. Recently discovered modular rhodopsins like rhodopsin guanylate cyclase (RhoGC) and rhodopsin phosphodiesterase (RhoPDE) paves the way to establish a proof of concept for utilization of complex rhodopsin (modular rhodopsin) for optogenetic applications. Light sensor coupled modular system could be expressed in any cell type and hence holds great potential in the advancement of optogenetics 2.0 which would enable manipulating the entire relevant cell signaling system. Here, we had identified 50 novel modular rhodopsins with variant domains and their diverse cognate signaling cascades encoded in a single ORF, which are associated with specialized functions in the cells. These novel modular algal rhodopsins have been characterized based on their sequence and structural homology with previously reported rhodopsins. The presented novel modular rhodopsins with various effector domains leverage the potential to expand the optogenetic tool kit to regulate various cellular signaling pathways across the diverse biological model systems.
\end{abstract}

Keywords: enzyme-rhodopsin; channelrhodopsins; optogenetics; two-component system; cyclase; phosphodiesterase

\section{Introduction}

The photobehavioural responses of many organisms are mediated by the rhodopsin-based photoreceptor(s) that are distributed across almost all clades of life. Rhodopsins are seven-transmembrane helical proteins that use retinal as a chromophore. Based on the isoforms of the retinal bound in the ground state, rhodopsins are classified into two broad categories i.e., Type I or microbial type (MTR) and Type II or animal-type rhodopsins (ATR). MTRs are widely distributed across all kingdoms of life and perform diverse physiological functions, such as the light-activated ion pump Bacteriorhodopsin (BR) [1] and Halorhodopsin (HR) [2], light-gated channel Channelrhodopsins (ChR1 \& ChR2) [3,4], and sensory photoreceptors (SRI \& II) [5]. Light-gated ion pumps and channels cause alterations in the 
membrane potential in a light-dependent manner whereas sensory rhodopsins mediate downstream signaling. SRI and II in halobacteria communicate with the flagellar motor via the transducer proteins HtrI and HtrII, respectively [5].

ATR or type II rhodopsins are broadly classified as vertebrate and invertebrate rhodopsins based on variation in their amino acid sequences [6]. The ATRs (both vertebrate and invertebrate) mediate the downstream signaling cascade through the G-protein that involves multiple steps and protein complexes. Both the ATRs as well as the SRs of MTRs are multi-component systems that require a series of protein complexes to mediate the light-activated signaling. This limits their use as an optogenetic tool for regulating intracellular signaling processes. The success of MTRs as an optogenetic tool is mainly attributed to their property that both the light-sensing and the ion channel activity of the Channelrhodopsins (ChRs) are encoded in a single protein. Recent advancements in the genome database have led to the discovery of many new MTRs that are directly coupled to effector domains, e.g., two-component system and cyclase in enzyme-rhodopsins $[7,8]$. This structural diversity imparts great precision, fast kinetics, and low off-target effects that provide an edge to the MTRs to target and regulate specific cellular processes simply by illumination. cAMP and cGMP, the key modulators of cell signaling, are the secondary messengers that regulate many cellular, metabolic, and developmental processes. However, it is difficult to target/modulate cGMP and cAMP levels precisely in specific cell types with spatiotemporal resolution using the animal-type rhodopsin signaling cascade because of the involvement of many players in the cascade. In addition, pharmacological targeting has the limitation of specificity and temporal issues at the cellular level.

Enzyme-rhodopsins (Rhodopsin phosphodiesterase; RhoPDE and Rhodopsin guanylate cyclase; RhoGC) have emerged as promising optogenetic tools for the precise and non-invasive spatiotemporal control of cyclic nucleotide signaling pathways. The heterologous expression of RhoPDE $[9,10]$ from Salpingoeca rosetta in Xenopus oocyte and HEK293 cell lines demonstrated the light-activated cGMP and cAMP-phosphodiesterase activity [11]. Similarly, RhoGC [12,13] isolated from fungi Blastocladiella emersonii and Catenaria anguillulae when expressed in various mammalian cell lines, could generate substantial cGMPs $[14,15]$. Furthermore, the existing rhodopsins can be modified via mutations or new sequences can be searched to overcome the current shortcomings of the optogenetic field by means of the optogenetic toolbox v2.0 [16]. Consequently, significant interest has developed towards the identification, characterization, and testing of novel modular rhodopsins $[7,17,18]$ as optogenetic tool candidates for tweaking the cell signaling processes. The identified modular rhodopsins coupled with other domains in a single ORF have shown the potential to overcome the limitation of SRs to be used as an optogenetic tool. Characterizing the physiological role of the existing and newly identified multidomain rhodopsins is tempting but limited because of their large transcript size, poor heterologous expression of the transmembrane domain, and lack of the established functional assays for these modular rhodopsins. Recently, we have identified several new modular rhodopsins from different algae [7]. In the present study, we have identified fifty new modular rhodopsins and ChRs fused with new domains that were previously unknown and analyzed their evolutionary pattern, sequence homology as well as the structural and functional potential of these domains coupled to rhodopsin (based on available experimental evidence). We have also investigated the diversity of multidomain rhodopsins and the recruitment of signaling components in a single ORF in relation to its prokaryotic counterpart. This extensive analysis of MTRs defines a future roadmap towards the involvement of modular rhodopsin-based photoreceptors in the photophysiological response of the relevant organism. Evolutionary pattern analysis of the MTRs suggests the evolution of multi-domain rhodopsins in the microalgal system after the evolution of the ChRs with extended C-terminus of unknown function by lateral gene transfer. Moreover, these novel modular rhodopsins with different effector domains strengthen the potential to expand the optogenetics tool kit 2.0 to regulate various cellular signaling pathways across a multitude of biological model systems. 


\section{Materials and Methods}

\subsection{Identification of Rhodopsin Domain, Homology and Structural Analysis}

Extensive genome database search for MTRs and modular rhodopsins were performed on the JGI genome database, metagenome database, and NCBI portal using BR and Chlamydomonas rhodopsin as a template. The rhodopsin identity, sequence accession number, homology, conserved domains, are summarized in Table S1. Multiple sequence alignment was performed using the Clustal_ $X$ program [19] and BioEdit (http://www.mbio.ncsu.edu/bioedit/bioedit.html). All color editing was done by using the BioEdit program. The rhodopsin domains of new MTRs were identified by sequence alignment with canonical rhodopsins, analyzed with conserved domain architecture retrieval tool (CDART) [20] and conserved domain database [21] programs. The rhodopsins with conserved seven transmembrane helices and retinal binding motif in the seventh helix were considered for further analysis. The number indicating the position of amino acid is referred with respect to BR unless mentioned in the text.

\subsection{Evolutionary Analysis of Rhodopsin Domains of Modular Proteins}

Molecular evolutionary analysis of typical MTR and rhodopsin domains (helices 1-7) of modular proteins was performed computationally with protein sequences. Multiple sequence alignment of the rhodopsin domain was done on Clustal X 2.0 [19]. Phylogenetic analysis was performed by the Neighbor-joining (NJ) method using MEGA X [22] with a thousand bootstrap replicates. The same was also verified by the maximum likelihood (ML) method on MEGA X. The topology was viewed by MEGA $X$ as well as by tree view and NJ plot [23].

\subsection{Protein-Protein Interaction Analysis of Novel Domains from Modular Algal Rhodopsins}

The interactomes of effector domain(s) associated with ChRs, i.e., FimV, MED15, and UL36, were constructed. The interacting partners for each of the effector domains were predicted using the String version 11 [24] and the output was further used to generate the network by employing Cytoscape 3.7.2 [25].

\section{Results and Discussion}

\subsection{Microbial Rhodopsins With Modular Domain Organization}

Mining the genome database of the organisms from diverse taxa and strata revealed the presence of MTRs in various organisms inhabiting diverse habitats from freshwater to terrestrial environments. The phototactic green alga C. reinhardtii is an excellent system to study and learn various aspects of cell biology ranging from the photobehavioural responses (especially ChR-mediated) to photosynthesis, cilia biology, intraflagellar transport to vesicle, and membrane-bound trafficking and dynamics [26,27]. Steady progress on unraveling the photobehavioural response in Chlamydomonas led to the early discovery of modular rhodopsins in this green alga but since then very few have been reported in other organisms.

Here, we have identified new microbial modular ChRs (Figure 1A and Table 1A,B) and modular sensory-type rhodopsins (Figure 1B-D and Table 2A,B) across different taxa and analyzed their critical features that segregate MTRs from other seven-transmembrane protein families. 
(A)

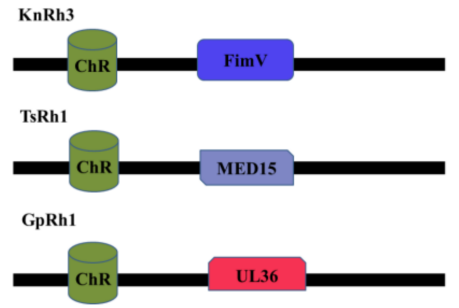

(B)

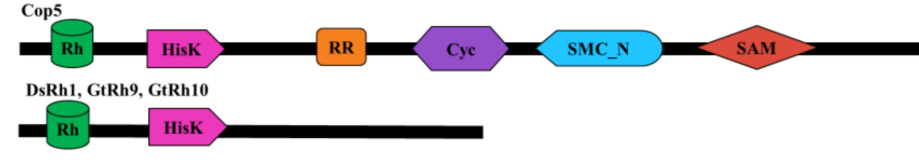

Cop7, Cop11, Cop12, Vop7, MpuRh1, MpuRh2, MspRh1, MspRh2, OtRh1, OIRh1-4 GpRh2, CsRh1, ApRh1, BgRh1, BgRh2, GtRh4-8

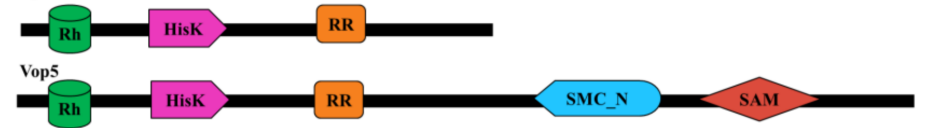

Vop6, Vop8, GpRh3, AsRh1, AsRh2, AsRh3
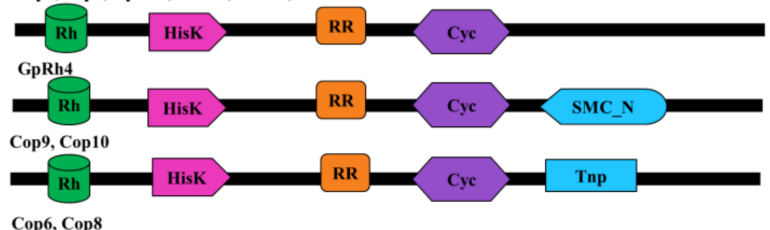

Cop6, Cop8

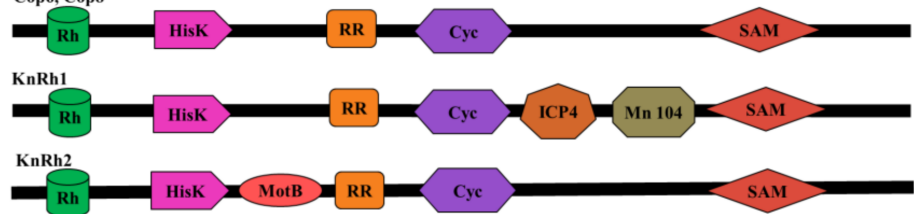

(C) GpRh5

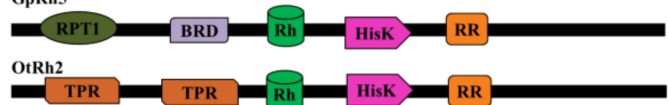

(D)

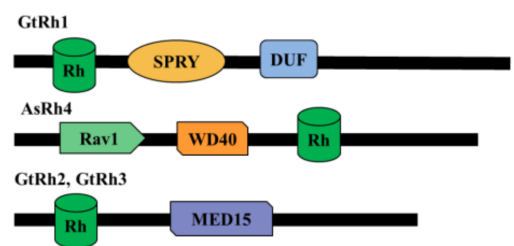

Figure 1. Schematic representation of domains present in modular microbial type rhodopsins. The schematic representation shows rhodopsin with modular domain(s), the black line represents full-length protein, and domains are depicted by geometric structures (Figure not to scale). (A) Domain organization of modular Channelrhodopsins (ChRs). ChR coupled with FimV (peptidoglycan binding protein), MED15 (mediator of RNA polymerase transcription factor subunit 15), and UL36 (large tegument protein) were found in three different algae. (B) Rhodopsin coupled HisK and RR form the largest group of modular domains and others have additional unique effector domains like cyclase (Суc), sterile alpha subunit (SAM), structural maintenance of chromosome_N-terminus (SMC_N), transposase (Tnp2), major viral transcription factor ICP4 homolog (ICP4), 104kDa microneme/rhoptry (Mn 104) and bacterial flagellar motor protein (MotB). (C) Modular rhodopsin with rhodopsin preceded by unique domain at N-terminus; ATP-dependent 26S proteasome (RPT1) and bromodomain (BRD) inGpRh5 and tricopeptide (TPR) in OtRh2. (D) Modular rhodopsin lacking HisK and RR; GtRh1 possesses Spore lysis A and Ryanodine receptor (SPRY) domain that regulates innate and adaptive immune response and domain of unknown function (DUF), GtRh2 and 3 possess MED15. AsRh1 possesses regulator of V-ATPase of vacuolar membrane protein 1 (Rav1) and WD40 at N-terminus. 
Table 1. (A)Modular Domains Coupled With Channelrhodopsins. (B) Modular Domains Coupled With Channelrhodopsins.

(A)

\begin{tabular}{ccc}
\hline Modular Domain & Channelrhodopsin & Functional Role and Optogenetic Potential \\
\hline $\begin{array}{c}\text { FimV } \\
\text { (Peptidoglycan binding protein) }\end{array}$ & KnRh3 & $\begin{array}{c}\text { In bacteria: Controls bacterial pathogenesis by indirectly } \\
\text { activating adenylyl cyclase and hence cAMP level. }\end{array}$ \\
\hline $\begin{array}{c}\text { MED15 } \\
\text { (Subunit of mediator complex) }\end{array}$ & TsRh1 & $\begin{array}{c}\text { In mammals: Regulates cholesterol and lipid homeostasis. } \\
\text { Promotes cancerous growth and is used as a biomarker } \\
\text { for malignancies. }\end{array}$ \\
\hline $\begin{array}{c}\text { UL36 } \\
\text { (Large tegument protein) }\end{array}$ & GpRh1 & Regulates viral entry to the cells. \\
\hline
\end{tabular}

(B)

\begin{tabular}{cccccc}
\hline Function of the Residue & $\begin{array}{c}\text { Proton } \\
\text { Acceptor }\end{array}$ & $\begin{array}{c}\text { Proton } \\
\text { Donor }\end{array}$ & DC Gate & $\begin{array}{c}\text { Stabilizes } \\
\text { Proton Acceptor }\end{array}$ & $\begin{array}{c}\text { Retinal } \\
\text { Attachment }\end{array}$ \\
\hline No. corresponds to ChR2 & 253 & 156 & 128 & 120 & 257 \\
\hline ChR2 & $\mathrm{D}_{253}$ & $\mathrm{D}_{156}$ & $\mathrm{C}_{128}$ & $\mathrm{R}_{120}$ & $\mathrm{~K}_{257}$ \\
\hline KnRh3 & $\mathrm{D}_{250}$ & $\mathrm{D}_{154}$ & $\mathrm{C}_{126}$ & $\mathrm{R}_{118}$ & $\mathrm{~K}_{254}$ \\
\hline TsRh1 & $\mathrm{D}_{236}$ & $\mathrm{D}_{139}$ & $\mathrm{C}_{111}$ & $\mathrm{R}_{103}$ & $\mathrm{~K}_{240}$ \\
\hline GpRh1 & $\mathrm{D}_{213}$ & $\mathrm{D}_{116}$ & $\mathrm{C}_{88}$ & $\mathrm{R}_{80}$ & $\mathrm{~K}_{217}$ \\
\hline
\end{tabular}

Table 2. (A) Modular Domains Coupled With Sensory-Type Rhodopsins. (B) Conserved Amino acid Residues of Sensory-Type Rhodopsins.

(A)

\begin{tabular}{|c|c|c|}
\hline Modular Domain & Modular Rhodopsins & Cellular Role and Optogenetic Potential \\
\hline HisK & $\begin{array}{l}\text { DsRh1, GtRh4-10, Cop5-12, Vop5-8, AsRh1-3, } \\
\text { GpRh2-5, KnRh1 \& 2, OtRh1\&2, OlRh1-4, } \\
\text { MpuRh1\&2, Msp1\&2, CsRh1, ApRh1, BgRh1\&2 }\end{array}$ & $\begin{array}{l}\text { Part of two-component signaling; regulates gene } \\
\text { expression }\end{array}$ \\
\hline $\begin{array}{c}\text { HisK-RR (Histidine } \\
\text { kinase-response regulator) } \\
\text { Two-component signaling system }\end{array}$ & $\begin{array}{c}\text { GtRh4-8, Cop5-12, Vop5-8, AsRh1-3, GpRh2-5, } \\
\text { KnRh1 \& 2, OtRh1\&2, OlRh1-4, MpuRh1\&2, } \\
\text { Msp1\&2, CsRh1, ApRh1, BgRh1\&2 }\end{array}$ & $\begin{array}{l}\text { Regulates gene expression and various other cell } \\
\text { processes via output domain like helix-turn-helix } \\
\text { (HTH), RNA, enzyme, or ligand-binding domain. }\end{array}$ \\
\hline Cyc (Cyclase) & $\begin{array}{c}\text { Cop5, 6, 8, } 9 \& 10, \text { Vop6\&8, AsRh1-3, GpRh3\&4, } \\
\text { KnRh1 \& } 2\end{array}$ & $\begin{array}{c}\text { Regulates the level of secondary messengers: } \\
\text { cAMP and cGMP. }\end{array}$ \\
\hline $\begin{array}{l}\text { SMC_N (Structural Maintenance } \\
\text { of chromosome_N terminal) }\end{array}$ & Cop5, Vop5, GpRh4 & $\begin{array}{l}\text { Stabilizes the chromosome, helps in its proper } \\
\text { segregation during cell division and DNA repair. }\end{array}$ \\
\hline Tnp (Transposase) & Cop9 \& 10 & $\begin{array}{l}\text { Recognizes the transposable elements in DNA and } \\
\text { catalyzes their movement to another DNA. }\end{array}$ \\
\hline SAM (Sterile alpha motif) & Cop5-8, Vop5, KnRh1 \& 2 & $\begin{array}{l}\text { Mediate protein-protein interactions, RNA and } \\
\text { lipid binding; regulates transcription factor }\end{array}$ \\
\hline ICP4 (Infected-cell polypeptide 4) & KnRh1 & $\begin{array}{l}\text { Major transcription factor of herpes simplex virus } \\
\text { type1 (HSV-1) }\end{array}$ \\
\hline Mn104 (Microneme/rhoptry) & KnRh1 & $\begin{array}{c}\text { Helps in invading host cell by apicomplexan } \\
\text { parasites; N-terminal region proposed to serve as a } \\
\text { signal peptide for ER }\end{array}$ \\
\hline MotB (Flagellar motor protein) & KnRh2 & MotB acts as a stator in the proton pump. \\
\hline $\begin{array}{c}\text { RPT1 (Regulatory Particle Triple } \\
\text { ATPase) }\end{array}$ & GpRh5 & Forms a part of $26 \mathrm{~S}$ proteasomal complex \\
\hline BRD (Bromodomain) & GpRh5 & $\begin{array}{l}\text { Modulate gene expression by associating with } \\
\text { acetylated lysine on histone }\end{array}$ \\
\hline
\end{tabular}


Table 2. Cont.

\begin{tabular}{ccc}
\hline Modular Domain & Modular Rhodopsins & Cellular Role and Optogenetic Potential \\
\hline TPR (Tetracopeptide repeat) & OtRh2 & $\begin{array}{c}\text { Regulates virulence in bacteria; translocation of } \\
\text { receptors to their respective organelles in different } \\
\text { systems }\end{array}$ \\
\hline $\begin{array}{c}\text { SPRY [Spore lysis A (Spl A) in Dictyostelium } \\
\text { discoideum } \begin{array}{c}\text { and mammalian Ryanodine } \\
\text { receptor (RYR)] }\end{array}\end{array}$ & GtRh1 & $\begin{array}{c}\text { Substrate binding for ubiquitination in ubiquitin ligase } \\
\text { family proteins; involved in the various immune } \\
\text { response }\end{array}$ \\
\hline $\begin{array}{c}\text { DUF (Domain of unknown function) } \\
\text { Rav1 }\end{array}$ & GtRh1 & $\begin{array}{c}\text { Mediate protein-protein interaction and transcription } \\
\text { repression; ATP dependent protein kinase; enzymatic } \\
\text { part of dicer; virulence and pathogenesis. }\end{array}$ \\
\hline $\begin{array}{c}\text { Regulator of V-ATPase of vacuole } \\
\text { membrane protein 1) }\end{array}$ & AsRh4 & $\begin{array}{c}\text { Regulates the assembly of V-ATPase (ATP powered H+ } \\
\text { pump in vacuole forming organelles) }\end{array}$ \\
\hline WD40 & AsRh4 & Mediate protein-protein interaction \\
\hline
\end{tabular}

(B)

\begin{tabular}{|c|c|c|c|c|c|c|c|c|}
\hline \multirow{2}{*}{$\begin{array}{l}\text { Function of the Residue } \\
\text { No. corresponds to BR }\end{array}$} & \multicolumn{5}{|c|}{ Ion Pumping } & \multicolumn{2}{|c|}{$\begin{array}{c}\text { Proton-Release to } \\
\text { Outside }\end{array}$} & \multirow{2}{*}{$\begin{array}{c}\begin{array}{c}\text { Retinal } \\
\text { Attachment }\end{array} \\
216\end{array}$} \\
\hline & 85 & 89 & 90 & 96 & 212 & 194 & 204 & \\
\hline BR & $\mathrm{D}$ & $\mathrm{T}$ & $\mathrm{T}$ & $\mathrm{D}$ & $\mathrm{D}$ & $\mathrm{E}$ & $\mathrm{E}$ & $\mathrm{K}$ \\
\hline HR & $\mathrm{T}_{90}$ & $\mathrm{~S}_{94}$ & $\mathrm{~T}_{95}$ & $\mathrm{~A}_{101}$ & $\mathrm{D}_{217}$ & $\mathrm{E}_{198}$ & $\mathrm{~T}_{209}$ & $\mathrm{~K}_{221}$ \\
\hline $\mathrm{KR} 2(\mathrm{Na}+)$ & $\mathrm{N}_{112}$ & $\mathrm{D}_{116}$ & $V_{117}$ & $\mathrm{Q}_{123}$ & $\mathrm{D}_{251}$ & $\mathrm{~L}_{227}$ & $\mathrm{R}_{243}$ & $\mathrm{~K}_{255}$ \\
\hline ASR1 & $\mathrm{D}_{75}$ & $\mathrm{~T}_{79}$ & $\mathrm{~T}_{80}$ & $\mathrm{~S}_{86}$ & $\mathrm{P}_{206}$ & $\mathrm{~S}_{188}$ & $\mathrm{D}_{198}$ & $\mathrm{~K}_{210}$ \\
\hline SR2 & $\mathrm{D}_{75}$ & $\mathrm{~T}_{79}$ & $\mathrm{~T}_{80}$ & $\mathrm{~F}_{86}$ & $\mathrm{D}_{201}$ & $\mathrm{~L}_{188}$ & $\mathrm{D}_{193}$ & $\mathrm{~K}_{205}$ \\
\hline RhoGC & $\mathrm{E}_{254}$ & $\mathrm{~T}_{258}$ & $\mathrm{C}_{259}$ & $\mathrm{~L}_{265}$ & $\mathrm{D}_{380}$ & $S_{364}$ & $\mathrm{~A}_{372}$ & $\mathrm{~K}_{384}$ \\
\hline RhoPDE & $\mathrm{E}_{164}$ & $\mathrm{~T}_{168}$ & $\mathrm{C}_{167}$ & $\mathrm{~W}_{175}$ & $\mathrm{D}_{292}$ & $\mathrm{Q}_{276}$ & $\mathrm{G}_{284}$ & $\mathrm{~K}_{296}$ \\
\hline AsRh4 & $\mathrm{D}_{2593}$ & $\mathrm{~T}_{2597}$ & $\mathrm{~T}_{2598}$ & $\mathrm{D}_{2604}$ & $\mathrm{D}_{2718}$ & $\mathrm{G}_{2701}$ & $E_{2710}$ & $K_{2722}$ \\
\hline GtRh1 & $\mathrm{F}_{152}$ & $\mathrm{~S}_{156}$ & $\mathrm{~T}_{157}$ & $\mathrm{I}_{163}$ & $\mathrm{D}_{297}$ & $\mathrm{G}_{280}$ & $\mathrm{~K}_{289}$ & $\mathrm{~K}_{301}$ \\
\hline GtRh2/3 & $\mathrm{D}_{95}$ & $\mathrm{~T}_{99}$ & $C_{100}$ & $\mathrm{~T}_{106}$ & $\mathrm{D}_{248}$ & $\mathrm{~T}_{232}$ & $\mathrm{E}_{240}$ & $\mathrm{~K}_{252}$ \\
\hline Cop5 & $\mathrm{M}_{113}$ & $\mathrm{~T}_{117}$ & $\mathrm{~T}_{118}$ & $\mathrm{~L}_{124}$ & $\mathrm{D}_{239}$ & $\mathrm{M}_{223}$ & $\mathrm{E}_{231}$ & $\mathrm{~K}_{243}$ \\
\hline Cop6 & $\mathrm{Q}_{170}$ & $\mathrm{~T}_{174}$ & $\mathrm{~T}_{175}$ & $\mathrm{I}_{181}$ & $\mathrm{~N}_{294}$ & $\mathrm{~V}_{279}$ & - & $\mathrm{K}_{298}$ \\
\hline Cop7 & $\mathrm{Q}_{161}$ & $\mathrm{~S}_{165}$ & $\mathrm{~T}_{166}$ & $\mathrm{M}_{172}$ & $\mathrm{D}_{287}$ & $\mathrm{~W}_{271}$ & $\mathrm{E}_{279}$ & $\mathrm{~K}_{291}$ \\
\hline Cop8 & $\mathrm{L}_{67}$ & $\mathrm{~T}_{71}$ & $\mathrm{~A}_{72}$ & $\mathrm{I}_{78}$ & $\mathrm{D}_{194}$ & $\mathrm{D}_{178}$ & $\mathrm{~S}_{186}$ & $\mathrm{~K}_{198}$ \\
\hline Cop9-10 & $\mathrm{L}_{141}$ & $\mathrm{~T}_{145}$ & $\mathrm{~A}_{146}$ & $\mathrm{I}_{152}$ & $\mathrm{D}_{268}$ & $\mathrm{D}_{252}$ & $\mathrm{~S}_{260}$ & $\mathrm{~K}_{272}$ \\
\hline Cop11 & $\mathrm{C}_{95}$ & $\mathrm{~T}_{99}$ & $\mathrm{~T}_{100}$ & $\mathrm{~L}_{106}$ & $\mathrm{D}_{279}$ & $\mathrm{~L}_{263}$ & $\mathrm{E}_{271}$ & $\mathrm{~K}_{283}$ \\
\hline Cop12 & $\mathrm{C}_{95}$ & $\mathrm{~T}_{99}$ & $\mathrm{~T}_{100}$ & $\mathrm{~L}_{106}$ & $\mathrm{D}_{221}$ & $\mathrm{~L}_{205}$ & $\mathrm{E}_{213}$ & $\mathrm{~K}_{225}$ \\
\hline Vop5 & $\mathrm{M}_{157}$ & $\mathrm{~T}_{161}$ & $\mathrm{~T}_{162}$ & $\mathrm{~L}_{168}$ & $\mathrm{D}_{283}$ & $\mathrm{~L}_{267}$ & $\mathrm{E}_{275}$ & $K_{287}$ \\
\hline Vop6 & $\mathrm{Q}_{153}$ & $\mathrm{~T}_{157}$ & $\mathrm{~T}_{158}$ & $\mathrm{I}_{164}$ & $\mathrm{~N}_{278}$ & $\mathrm{~L}_{263}$ & - & $\mathrm{K}_{282}$ \\
\hline Vop7 & $\mathrm{Q}_{147}$ & $\mathrm{~S}_{151}$ & $\mathrm{~T}_{152}$ & $\mathrm{M}_{158}$ & $\mathrm{D}_{272}$ & $\mathrm{~W}_{256}$ & $\mathrm{E}_{264}$ & $\mathrm{~K}_{276}$ \\
\hline MspRh1 & $\mathrm{E}_{140}$ & $\mathrm{~T}_{144}$ & $\mathrm{~T}_{145}$ & $\mathrm{I}_{151}$ & $\mathrm{D}_{284}$ & $\mathrm{~F}_{268}$ & $\mathrm{Q}_{276}$ & $\mathrm{~K}_{288}$ \\
\hline MspRh2 & $\mathrm{E}_{142}$ & $\mathrm{G}_{146}$ & $\mathrm{~T}_{147}$ & $\mathrm{~L}_{153}$ & $\mathrm{D}_{299}$ & $\mathrm{~S}_{283}$ & $\mathrm{~L}_{291}$ & $\mathrm{~K}_{303}$ \\
\hline MpuRh1 & $\mathrm{E}_{140}$ & $\mathrm{~T}_{144}$ & $\mathrm{~T}_{145}$ & $\mathrm{I}_{151}$ & $\mathrm{D}_{300}$ & $\mathrm{~F}_{284}$ & $\mathrm{Q}_{292}$ & $\mathrm{~K}_{304}$ \\
\hline MpuRh2 & $\mathrm{S}_{151}$ & $\mathrm{~S}_{155}$ & $\mathrm{~T}_{156}$ & $\mathrm{~L}_{162}$ & $\mathrm{D}_{328}$ & $\mathrm{~A}_{312}$ & $\mathrm{~A}_{320}$ & $\mathrm{~K}_{332}$ \\
\hline GtRh4 & $\mathrm{Q}_{92}$ & $\mathrm{~T}_{96}$ & $\mathrm{~T}_{97}$ & $\mathrm{~V}_{103}$ & $\mathrm{D}_{225}$ & $\mathrm{~S}_{209}$ & $\mathrm{Y}_{217}$ & $\mathrm{~K}_{229}$ \\
\hline
\end{tabular}


Table 2. Cont.

\begin{tabular}{|c|c|c|c|c|c|c|c|c|}
\hline \multirow{2}{*}{$\begin{array}{c}\text { Function of the Residue } \\
\text { GtRh5 }\end{array}$} & \multicolumn{5}{|c|}{ Ion Pumping } & \multicolumn{2}{|c|}{$\begin{array}{c}\text { Proton-Release to } \\
\text { Outside }\end{array}$} & \multirow{2}{*}{$\begin{array}{c}\begin{array}{c}\text { Retinal } \\
\text { Attachment }\end{array} \\
\mathrm{K}_{359}\end{array}$} \\
\hline & $\mathrm{Q}_{222}$ & $\mathrm{~T}_{226}$ & $\mathrm{~T}_{227}$ & $\mathrm{~V}_{233}$ & $\mathrm{D}_{355}$ & $\mathrm{G}_{339}$ & $\mathrm{Y}_{347}$ & \\
\hline GtRh6 & $\mathrm{Q}_{234}$ & $\mathrm{~T}_{238}$ & $\mathrm{~T}_{239}$ & $\mathrm{~V}_{245}$ & $\mathrm{D}_{367}$ & $\mathrm{G}_{351}$ & $\mathrm{Y}_{359}$ & $\mathrm{~K}_{371}$ \\
\hline GtRh7 & $\mathrm{Q}_{116}$ & $\mathrm{~T}_{120}$ & $\mathrm{~T}_{121}$ & $\mathrm{~V}_{127}$ & $\mathrm{D}_{249}$ & $\mathrm{~S}_{233}$ & $\mathrm{Y}_{241}$ & $\mathrm{~K}_{253}$ \\
\hline GtRh8 & $\mathrm{Q}_{226}$ & $\mathrm{~T}_{230}$ & $\mathrm{~T}_{231}$ & $\mathrm{~V}_{237}$ & $\mathrm{D}_{359}$ & $\mathrm{~L}_{343}$ & $\mathrm{Y}_{351}$ & $\mathrm{~K}_{363}$ \\
\hline GtRh9 & $\mathrm{Q}_{229}$ & $\mathrm{~T}_{233}$ & $\mathrm{~T}_{234}$ & $\mathrm{I}_{240}$ & $\mathrm{D}_{362}$ & $\mathrm{~L}_{346}$ & $\mathrm{Y}_{354}$ & $\mathrm{~K}_{366}$ \\
\hline GtRh10 & $\mathrm{Q}_{192}$ & $\mathrm{~T}_{196}$ & $\mathrm{~T}_{197}$ & $\mathrm{~V}_{203}$ & $\mathrm{D}_{325}$ & $\mathrm{~L}_{309}$ & $\mathrm{~F}_{317}$ & $\mathrm{~K}_{329}$ \\
\hline BgRh1/2 & $\mathrm{E}_{173}$ & $\mathrm{~T}_{177}$ & $\mathrm{~T}_{178}$ & $\mathrm{~S}_{184}$ & $\mathrm{D}_{302}$ & $\mathrm{~L}_{286}$ & $\mathrm{E}_{294}$ & $\mathrm{~K}_{306}$ \\
\hline OtRh1 & $\mathrm{E}_{181}$ & $\mathrm{~T}_{185}$ & $\mathrm{~T}_{186}$ & $\mathrm{~L}_{192}$ & $\mathrm{D}_{314}$ & $\mathrm{M}_{298}$ & $\mathrm{E}_{306}$ & $\mathrm{~K}_{318}$ \\
\hline OtRh2 & $\mathrm{E}_{476}$ & $\mathrm{~T}_{480}$ & $\mathrm{~T}_{481}$ & $\mathrm{~L}_{487}$ & $\mathrm{D}_{609}$ & $\mathrm{M}_{593}$ & $\mathrm{E}_{601}$ & $\mathrm{~K}_{613}$ \\
\hline OlRh1 & $E_{204}$ & $\mathrm{~T}_{208}$ & $\mathrm{~T}_{209}$ & $\mathrm{~L}_{215}$ & $\mathrm{D}_{337}$ & $\mathrm{~L}_{321}$ & $\mathrm{E}_{329}$ & $\mathrm{~K}_{341}$ \\
\hline OlRh2 & $E_{260}$ & $\mathrm{~T}_{264}$ & $\mathrm{~T}_{265}$ & $\mathrm{~L}_{271}$ & $\mathrm{D}_{393}$ & $\mathrm{~L}_{377}$ & $\mathrm{E}_{385}$ & $\mathrm{~K}_{397}$ \\
\hline OlRh3 & $\mathrm{E}_{188}$ & $\mathrm{~T}_{192}$ & $\mathrm{~T}_{193}$ & $\mathrm{~L}_{199}$ & $\mathrm{D}_{321}$ & $\mathrm{~L}_{305}$ & $\mathrm{E}_{313}$ & $\mathrm{~K}_{325}$ \\
\hline OlRh4 & $E_{115}$ & $\mathrm{~T}_{119}$ & $\mathrm{~T}_{120}$ & $\mathrm{~L}_{126}$ & $\mathrm{D}_{248}$ & $\mathrm{~L}_{232}$ & $\mathrm{E}_{240}$ & $\mathrm{~K}_{252}$ \\
\hline DsRh1 & $\mathrm{Q}_{140}$ & $\mathrm{~S}_{144}$ & $\mathrm{~T}_{145}$ & $\mathrm{M}_{151}$ & $\mathrm{D}_{268}$ & $\mathrm{~L}_{252}$ & $\mathrm{E}_{260}$ & $\mathrm{~K}_{272}$ \\
\hline GpRh2 & $\mathrm{C}_{91}$ & $\mathrm{~T}_{95}$ & $\mathrm{~T}_{96}$ & $\mathrm{~L}_{102}$ & $\mathrm{D}_{217}$ & $\mathrm{~L}_{201}$ & $\mathrm{E}_{209}$ & $\mathrm{~K}_{221}$ \\
\hline GpRh3 & $\mathrm{Q}_{85}$ & $\mathrm{~T}_{89}$ & $\mathrm{~T}_{90}$ & $\mathrm{I}_{96}$ & $\mathrm{~N}_{209}$ & $\mathrm{~A}_{194}$ & - & $\mathrm{K}_{213}$ \\
\hline GpRh4 & $\mathrm{M}_{67}$ & $\mathrm{~T}_{71}$ & $\mathrm{~T}_{72}$ & $\mathrm{~L}_{78}$ & $\mathrm{D}_{193}$ & $\mathrm{~L}_{177}$ & $\mathrm{E}_{185}$ & $\mathrm{~K}_{197}$ \\
\hline GpRh5 & $\mathrm{Q}_{1412}$ & $\mathrm{~S}_{1416}$ & $\mathrm{~T}_{1417}$ & $\mathrm{M}_{1423}$ & $\mathrm{D}_{1537}$ & $\mathrm{~L}_{1521}$ & $E_{1529}$ & $\mathrm{~K}_{1541}$ \\
\hline CsRh1 & $\mathrm{M}_{144}$ & $\mathrm{~A}_{148}$ & $\mathrm{~T}_{149}$ & $\mathrm{~T}_{155}$ & $\mathrm{D}_{269}$ & $\mathrm{~L}_{253}$ & $\mathrm{E}_{261}$ & $\mathrm{~K}_{273}$ \\
\hline ApRh1 & $\mathrm{M}_{67}$ & $A_{71}$ & $\mathrm{~T}_{72}$ & $\mathrm{~T}_{78}$ & $\mathrm{D}_{192}$ & $\mathrm{~A}_{176}$ & $\mathrm{E}_{184}$ & $\mathrm{~K}_{196}$ \\
\hline AsRh1 & $\mathrm{N}_{122}$ & $\mathrm{~T}_{126}$ & $\mathrm{~T}_{127}$ & $\mathrm{~L}_{133}$ & $\mathrm{~N}_{248}$ & $\mathrm{~L}_{232}$ & $\mathrm{~T}_{240}$ & $\mathrm{~K}_{252}$ \\
\hline AsRh2 & $\mathrm{N}_{123}$ & $\mathrm{~T}_{127}$ & $\mathrm{~T}_{128}$ & $\mathrm{~L}_{134}$ & $\mathrm{~N}_{249}$ & $\mathrm{~L}_{233}$ & $\mathrm{~S}_{241}$ & $\mathrm{~K}_{253}$ \\
\hline AsRh3 & $\mathrm{Q}_{78}$ & $\mathrm{~T}_{82}$ & $\mathrm{~T}_{83}$ & $\mathrm{~V}_{89}$ & $\mathrm{~N}_{203}$ & $\mathrm{~L}_{187}$ & $C_{195}$ & $\mathrm{~K}_{207}$ \\
\hline KnRh1 & $\mathrm{Q}_{166}$ & $\mathrm{~T}_{170}$ & $\mathrm{~T}_{171}$ & $\mathrm{M}_{177}$ & $\mathrm{D}_{292}$ & $\mathrm{~L}_{276}$ & $\mathrm{E}_{284}$ & $\mathrm{~K}_{296}$ \\
\hline KnRh2 & $\mathrm{Q}_{95}$ & $\mathrm{~T}_{99}$ & $\mathrm{~T}_{100}$ & $\mathrm{~L}_{106}$ & $\mathrm{E}_{221}$ & $\mathrm{~T}_{205}$ & $\mathrm{E}_{213}$ & $\mathrm{~K}_{225}$ \\
\hline
\end{tabular}

\subsection{Modular Channelrhodopsins and Their Optogenetic Potential}

Our targeted search for the modular ChR yielded three modular ChRs as shown in Figure 1A. These are KnRh3 from Klebsormidium nitens, TsRh1 from Tetraselmis subcordiformis, and GpRh1 from Gonium pectorale. KnRh3 is coupled with the peptidoglycan binding protein, FimV, whereas TsRh1 is the blue-shifted ChR for which the rhodopsin domain has been characterized [28]. TsRh1 is coupled with the mediator subunit, MED15 (Mediator of RNA polymerase II subunit 15) [28], however its modular nature has not been characterized and discussed. GpRh1 from Gonium pectorale is coupled with UL36 (large tegument protein). The optogenetic potentials of these modular domains (FimV, MED15, and UL36) are summarized in Table 1A. The Rhodopsin domains of KnRh3, TsRh1, and GpRh1 were aligned with well-characterized ChRs taken as the reference for sequence analysis (Figure 2). The conserved residues essential for photocycle are marked in Figure 2, and the same have been analyzed for four main functionalities namely: (1) retinal-binding lysine, (2) counter ion/proton acceptor of retinal Schiff base (RSB,) (3) stabilization of proton acceptor and, (4) DC-gate present in helix 3 and 4 . Based on these amino acid residues, we evaluated the rhodopsin domains and summarized the details in Tables $1 \mathrm{~B}$ and $2 \mathrm{~B}$ for modular ChRs and modular sensory-type rhodopsins, respectively. 


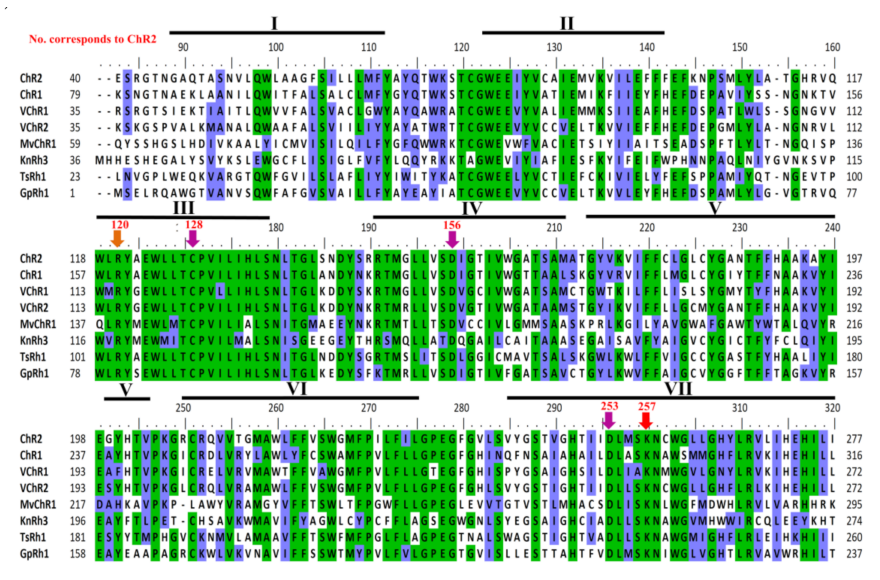

Figure 2. Comparison of novel channelrhodopsins and mapping of the important amino acid residues: Modular ChRs (KnRh3, TsRh1, and GpRh1) were aligned with other ChRs (ChR1 and ChR2 Figure 1. \& VChR2 from V. carteri, MvChR1 from M. viride. Helices 1-7 are depicted by a black bar and marked in roman numbers. Retinal binding lysine is marked by the red arrow; proton acceptor/donor and cysteine hydrogen-bonded to proton donor (DC pair) are marked by the pink arrow; arginine is important for primary translocation of the proton is marked by an orange arrow.

All the three ChRs have the conserved seven transmembrane domains and the lysine motif at the seventh helix that forms a covalent linkage with retinal (Figure 2 and Table 1B). Asp253 (in ChR2) accepts the proton from the RSB during deprotonation and Asp156 (in ChR2) donates the proton to the RSB during re-protonation. Both these sites are conserved in modular ChRs (Figure 2 and Table 1B). Arg82 (in BR) stabilizes the negatively charged proton acceptor Asp85 (in BR) and is hydrogen bonded to Tyr83 via water 405 in M state and together they play a primary role during deprotonation of RSB. The corresponding position in ChR2 (Arg120) is hydrogen-bonded to E253 (proton acceptor) and is the core of the extracellular gate participating in ion movement [29]. This site is highly conserved among MTRs including modular ChRs (Figure 2 and Table 1B). Asp156 (in ChR2) is hydrogen-bonded to Cys128 to form a DC-gate that acts as a switch for the movement of ions [30]. Mutation of Cys128 to $\mathrm{Thr}$ (C128T) delays the closure of the ion channel gate and therefore remains conducting for a longer period [31]. This mutation has enhanced the property of ChR2 to be used as an optogenetic tool. Cys128 is also conserved in newly identified modular ChRs (Figure 2 and Table 1B).

The conservation of important amino acids reflects their functionality and could be engineered to enhance their properties. Thus, newly identified modular ChRs hold the potential to be used as optogenetic tools for controlling new biological pathways.

Apart from the three modular ChRs, the genome database search also led to the identification of many modular sensory-type rhodopsins from different alga. A diverse set of domains fused with modular sensory-type rhodopsins were identified in a single ORF, which suggests multiple light-mediated cellular signaling pathways in these algae. Most of the identified rhodopsins are coupled with the two-component histidine kinase (HisK) and response regulator (RR) system. The first modular rhodopsin identified and characterized was Chlamyopsin5 (Cop5/HKR1) of C. reinhardtii [32].

\subsection{Modular Sensory-Type Rhodopsins and Their Optogenetic Potential}

In the Cop5 modular organization, rhodopsin was coupled with HisK and RR domain along with Cyc, SMC_N, and SAM (Figure 1B). Experimental evidence suggests that Cop5 localizes in the eyespot of $C$. reinhardtii, with dichromic absorbance maxima in the UV range however, their native functional role is still not clear [32]. Followed by Cop5, many other rhodopsins with similar domain architecture were identified in C. reinhardtii and other algae as well. Cop6-8 expressions were further confirmed in C. reinhardtii and Cop8 was localized in cilia and eyespot in a light-dependent manner [7]. Similar homologs of the modular rhodopsins were identified in another closely related colonial green 
algae Volvox carteri and other algae (Figure 1B). Along with HisK and RR, other domains like Cyc, SMC_N, Tnp, and SAM were also coupled in some modular rhodopsins as shown in Figure 1B. Interestingly, GpRh5 and OtRh2 possess domains (RPT1 and BRD in GpRh5; TPR in OtRh2) at the $\mathrm{N}$-terminus of rhodopsin and the two-component system at the C-terminus of rhodopsin (Figure 1C, Table 2A). Another group of modular rhodopsin lacks the two-component system but is coupled to a unique domain like SPRY, DUF, and MED15 (Figure 1D). AsRh4 is unique among this group in possessing Rav1 and WD40 at the N-terminus of rhodopsin (Figure 1D). We have summarized the modular sensory-type rhodopsins according to their domain architecture, cellular function, and possible optogenetic applications in Table 2A.

\subsection{Light-Gated Ion Pump and Photo-Sensory Function Prediction Based on Conserved Residues of Rhodopsins}

Amino acids in the proximity of retinal are the key determinants in the activation and function of rhodopsins. The crystal structure of BR suggests that Asp85 is the proton acceptor from RSB during deprotonation. Thr89 is hydrogen-bonded to Asp85 (Figure 3 and Table 2B). Thr90 forms a part of the retinal binding pocket and the corresponding position in ChR2 (Cys128) forms the DC-gate regulating the movement of ions. Asp212 forms a part of counterion and thus, plays a role during the primary proton transfer event. Asp96 donates a proton to the RSB during reprotonation. Glu194 and 204 are the terminal amino acids responsible for the outward release of protons to the extracellular side. These positions were analyzed in the modular rhodopsins to assign their functionality. Out of 47 modular rhodopsins at position 85, 14 had conserved Asp/Glu while 17 had Gln (Figure 3 and Table 2B). Position 89 is well conserved with 43 out of 47 modular rhodopsins possessing Ser/Thr at this position (Figure 3 and Table 2B). Asp96 is only conserved in AsRh4 (Table 2B). Asp212 is well conserved among modular rhodopsins except 6 of them which possess Asn at this position (Figure 3 and Table 2B). Only 4 modular rhodopsins possess Asp at 194th position while 25 modular rhodopsins have Glu at 204th position (Figure 3 and Table 2B). These rhodopsins seem to be functional since the retinal binding lysine is conserved among all of them (Figure 3 and Table 2B). AsRh4 is the only modular rhodopsin with an amino acid conserved for proton pump. Other modular rhodopsins seem to form a new group with a different mechanism for activation and relay of signals. Despite lacking the proton acceptor Asp85, Cop 5 was found to be active in UV-A and blue light (Figure 3 and Table 2B). Cop6/Vop6 behaves as a light inhibited guanylate cyclase in the presence of ATP when expressed in Xenopus oocyte [33] even though; it lacks Asp85, Asp96, and Asp212 (Figure 3 and Table 2B). The signal relay in Cop6/Vop6 proceeds through HisK and RR. OtRh1/Ot-HKR is a green absorbing modular rhodopsin controlling the circadian clock of $O$. tauri. The photophysical properties of OtRh1/Ot-HKR are affected by salt concentration indicating this rhodopsin might provide input for adaptation in the salt environment [34]. These examples suggest that the important amino acids are substituted but these rhodopsins are still functional. Unique domains coupled with rhodopsin might regulate specific function in cell/organism and hold potential to be used as optogenetic tools and therefore should be explored in detail. 


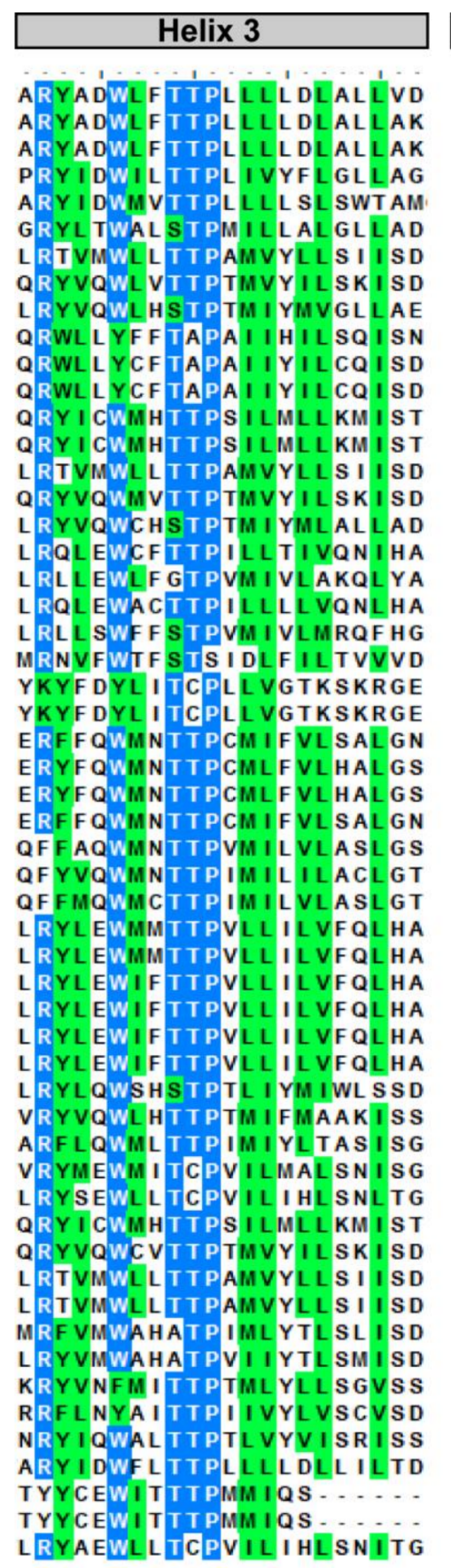

\section{Helix 4}

ALVGADG IM IGTG. TL VGVDAL M I VTG. TL I GVDAL M I VTG I V I TLNTVVIMLAG FLMSTQIVVITSG TV I A ADI GMCVTG SVMLADVLM I TFG TA I GLDVLMVLSG LPVLCDVAMVVTG VVLLNAFMLAAGG V IMLNVFMLAAGG VIMLNVFMLAAGG. I A I FFDE VIMVVTG I A I F F DE VMVVTG SVMLADVLM I SFG TA I CMDVVMVLSG VPLLSDVLMVASG VL I AADECMLLCG RL VQADVLMLVCGC AL I LADE LM I LCG HLAWGTVFML ACGC YLFM I NAAL HTCGV YAVYVQITIFTGFM YAVYVQ IT IFTGFM KCVL WDE AM IFAG. RVL I SDELM I LTG. RVL I SDELM I LTG. KCVL WDE AM I FAG RA I LWDE VML TLG NA I L WDE TML VLG NA I CWDE L ML VLG CAC I ADE I ML I TG CAC I ADE I ML I TG A I CVADE I ML I TG A I CVADE I ML I TG A I CVADE I ML I TG A I CVADE I ML I T G YAVANDVVM ILTG VAVLYDML MLATG. LNTF CDLF I L MVG. QLLATDQGA ILCA RLLVSDIGTIVFG. VA ILFDE IMVVTG TA I AMDVTMV I TG VVML ADVL M I AFG VVMLADVLM IAFG. QTLGVNVFM IVAV . RL VL VDL VM I VT I . ATAGMQWGCVVTG. GVAAMQAGVIAFG. LAVGAQVVV I VTG . WIMAADI FM I I FG. RIVVIRAQILN. RIVVIRAQILN... SLITSDLGGICMA .

\section{Helix 6}

ILRNVTVVLWSAYPVVWW ILTALVL VLWTAYPILW ILTAL VAVLWTAYPILW PL RNL TVILWA I YPF IW CLVTYF TVLWI GYPI VW ILRVL TVVLWL GYP I VW ILRLFAVGLWFTFPVIW :I YMCTLF IWNLFPLAW IVRALLLALWGAF PL VW : I R IFS I TTWNFFPIVY : IRLF S I TTWNLFPFVY : I RLF S I TTWNLFPFVY $\because$ Y YVLNL VLWCTFAA I TW : Y YVL NL VLWCTFA I TW ILRLFAVGLWFTF PGIW : I YMCTLL IWSMF PVAW IVLALLLALWSAF PVVW A IVALKVI AWSGYPITY ILAVF NVVSWCVFPTAY :I AAL KM I AWT VYPAVY ILVF INVCAWCVFPLVF ¿LVRVVI I TWSLYPALW TAL STYFC IWAVYPVLW IALSTYFC IWAVYPVLW LLE IFT I VLWSLFPLVH SLE I STFLLWSVFPVVH SLE I STFLLWSVFPVVH ILE IFT I VLWSLFPLVH ¡LEA I TYMLWNLFPSLH ЭI EWF TYMLWSLFPCVH ¿LQIYTYLLWL SFPTLH ILACAKT I CWT SFP IVY ILACAKT I CWT SFP IVY IL A I AKTVCWT SF PLVF IL A I AKTVCWTSFPLVFI ILA I AKTVCWT SF PLVF IL A I AKTVCWT SFPLVF IVLFLML GLWNL F PVVW : QAHMVF TWN IFPL VW LQIYILTTWTAFPCVA MIMAVIFYAGWL CYPCFF INAVIFFS SWTMYPVLF :I YVLLLL ILWCTFAVTW : I YMCTLL IWCL F PLAW ILRLFAVGLWFTFPA IW ILRLFAVGLWFTFPA IW ILRNF TL SFWTFF PCVW ILRASTAVFWTLFPF VW : I HNYSVVAWSLFPAAW :IF I YTVVLWSVFPATW : IFWSTVVVWLAFP I YW IMAVYL SVLWWGYPIVW VLR IFYTMTWML FPM IY ILRIFYTMTWMLPMIY MAAVFF TSWFMF PGLF

\section{Helix 7}

DVSAKVVGF̈GLIL 1 TKGB_BR DVTAKVGFGF IL 1UAZ_AR1 DVTAKVGFGFVL 1VGOAR? DLVTKVGFGF I A 1H2S_SRII PFFSKVGFSFLD 1XIO_ASR DVFAKYVFAF IL 1E12HR DFLGKVMFSSSL Cop5 NFMAKVLFSSSII Cop6 DYLAKAVF SSQL Cop7 DWL TKMVYSSSLI Cop8 DWL TKMVYSSSLI Cop9 DWL T KMVY S S SLI Cop10 DF SAKVLFSSTLI Cop11 DF SAKVLF S STLI Cop12 DFLGKVMFSSSL Vop5 NFFAKVLFSSS II Vop6 DYLAKVVFSSQLI Vop7 IDV I TKF SYTL I I MspRh1 iDAFAKF SCTMLY MspRh2 IDVLTKF SYSLVI MpuRh1 ¿DGCAKF SLSALY MpuRh? DF I SKF SF I AMF GtRh1 DVLAKSMYGFAL GtRh? IDVLAKSMYGFAL GtRh3 DLATKA I Y SVTL GERh4 D ILTKSVYTVTL GtRh5 'DILTKSVYTVTL GtRh6 DLATKA I Y SVTL GtRh? DVVVKA I Y SVALI GtRhB DVVAKAVYTVAL GtRh DVLAKA I YT VALI GtRh10 DVL TKAVYCLLL. OtRh1 DVLTKAVYCLLL. OtRh2 DVL TKAAYCLLL OIRh1 DVLTKAAYCLLL. OIRh? DVLTKAAYCLLL OIRh3 DVLTKKAAYCLLL. OIRh4 DYAAKAVFVSQLI DsRh1 DL SAKVVFSALL KnRh1 ELACKF VFSALL KnRh? 'DLL SKNAWG VMHI KnRh3 DL MSKN IWGL VG GpRh1 DF SAKVLFSSTLI GpRh2 NFMAKVLFSSS I GpRh3 DFLGKVMFSSSL GpRh4 DFL GKVMF S S SL GpRh5 DTMGKI IFSSTL CsRh1 DLGGKI IFSTSL ApRh1 NLL VAKLLYSSGI AsRh1 NWVAKVVYS SN II AsRh? NFVAKVLFSSS- AsRh3 D IVAKVVFGWIII AsRhA DL SAKVGLVNMA BgRh1 DL SAKVGL VNMA BgRh? DLL SKNAWGM I G TsRh1

Figure 3. Comparison of light sensor domain of the modular rhodopsin among different algae: Most conserved third, fourth, sixth, and seventh helices of rhodopsin are depicted here. Numbering was adapted according to the protein of BR. 1KGB: Bacteriorhodopsin, 1UAZ: Archaerhodopsin-1, 1VGO: Archaerhodopsin-2, 1El2: Halorhodopsin, 1H2S: Sensory Rhodopsin II, 1XIO: Anabaena sensory rhodopsin.

\subsection{Spectral Tuning of the New Microbial Rhodopsins}

The amino acid residues surrounding the chromophore are primarily responsible for tuning the absorbance maxima of the holoprotein rhodopsin. The significant role of amino acids in spectral tuning was studied in the case of green and blue proteorhodopsins (GPR and BPR, respectively). The amino acid residue at the 105th position of the highly homologous green absorbing proteorhodopsin (GPR: AY210898) and blue absorbing proteorhodopsin (BPR: AY210919) have nonpolar leucine and polar glutamine 
residues, respectively. The substitution of either convert it into the other form and vice versa [35]. The four rhodopsins of halobacteria BR, HR, SRI, and SRII have the same bound chromophore but SRII shows a blue-shifted absorbance at $498 \mathrm{~nm}$ as compared to BR, HR, and SRI by 60 to $80 \mathrm{~nm}$. Point mutations of all residues in the retinal pocket in archaeal SRII corresponding to BR did not shift the maxima of SRII to BR [36,37]. This suggests that spectral tuning is also regulated by other structural feature(s) of rhodopsins, probably by residues present at the flanking sides of the retinal binding pocket. The absorption spectrum of animal rhodopsin covers the entire visible range from UV-A to NIR. Absorbance maxima of MTRs are largely confined to the blue and green region of the spectra But, the recently characterized Cop5, modular rhodopsin coupled with HisK, RR, and Cyc suggest its tuning to UV-A and blue light (bi-stable switch). The chromophore isomerization and counterion distance were involved in spectral shift $[32,38,39]$. Based on the sequence analysis and comparison of residues corresponding to the 105th position (proteorhodopsin), the spectral shift (blue or green) of the modular rhodopsin has been analyzed and summarized in Table 3. This analysis suggests that newly identified modular rhodopsins are green tuned due to the presence of a nonpolar amino acid at the position corresponding to the 105th position (proteorhodopsin) except GtRh1 which possesses an acidic amino acid.

Table 3. Comparative Analysis of the Amino Acid Residues Determining Spectral Tuning of the Rhodopsin.

\begin{tabular}{cccc}
\hline Rhodopsin & $\begin{array}{c}\text { 105th Position/ Corresponding } \\
\text { Amino Acid }\end{array}$ & Polar/Non-Polar aa & Green/Blue Shifted \\
\hline Green PR & Leucine & Non-Polar & Green \\
\hline Blue PR & Glutamine & Polar & Blue \\
\hline $\begin{array}{c}\text { KnRh3, TsRh1 and } \\
\text { GpRh3 }\end{array}$ & Isoleucine & Non-polar & Green \\
\hline $\begin{array}{c}\text { Cop8-12, GpRh2, } \\
\text { ApRh1, AsRh2 }\end{array}$ & Isoleucine & Non-polar & Green \\
\hline $\begin{array}{c}\text { MspRh1, MpuRh1, } \\
\text { OlRh3-4, OtRh1-2, } \\
\text { GtRh2,3 }\end{array}$ & Leucine & Non-polar & Green \\
\hline $\begin{array}{c}\text { Cop5-7, Vop5-7, } \\
\text { GpR3-5, GtRh4-10, } \\
\text { AsRh1, MspRh2, } \\
\text { MpuRh2, CsRh1, }\end{array}$ & Methionine & & \\
BgRh1-2, KnRh1-2 & & Non-polar & Green \\
\hline GtRh1 & Aspartate & Acidic & unknown \\
\hline
\end{tabular}

In addition to blue and green-shifted MTRs, the red-shifted MTRs [40-44] have also been reported with advantages over the former such as better light penetration, less scattering by biological material, and reduced phototoxicity. Many factors were found to be responsible for the red-shift such as the substitution of amino acid residues near the retinal binding pocket, the protonation state of the counter-ion for RSB, and the distribution of polar amino acids [43]. These factors constitute a challenge to predict a model for the newly identified modular rhodopsins for their red-shifted spectral tuning. The blue and green tuned rhodopsins can be engineered to obtain the red-shifted molecules thereby making them suitable for optogenetic applications. Spectral response in long-wavelength ( 590 to $630 \mathrm{~nm}$ ) was achieved by the engineering of VChR1 named as red activated ChR, ReaChR (VChR1 with N terminus of CHEF/CHIEF, transmembrane helix F of VChR2 and point mutation Lue171Ile [45]). Point mutations (P219T/S254A) in the sodium ion pump (KR2) led to a red-shift of $40 \mathrm{~nm}$ without affecting its ion pumping activity [46]. The addition of the retinal analog 3-methylamino-16-nor-1,2,3,4-didehydroretinal (MMAR) led to a red-shift in the archaerhodopsin-3 absorption spectra [47]. The modular ChR would be expected not only to change the membrane potential 
but also to modulate the specific signaling pathways linked with coupled domains (Figure S3A,B). MED15 expression controls the malignancies and progression of the tumor, and suppression of MED15 leads to cancer progression. On a speculative note, the MED15 domain of ChR might be involved in reversing the light-mediated cellular toxicity in these organisms that depend on light for their photo-behavioral responses. Hence MED15 coupled ChRs might be an excellent tool for optogenetic stimulation of the cells. Moreover, other additional tools like genetic engineering, exogenous supply of other compounds like MMAR, etc., mentioned above to red-shift the spectral tuning might be the added benefits of their optogenetic applications.

\subsection{Evolutionary Pattern of the Modular Microbial Rhodopsins}

MTRs provide a smart alternative pathway of ATP production, other than photosynthesis, in archaea and help in the survival of the organism in harsh conditions. Many reports have been published regarding the evolutionary pattern of MTRs $[48,49]$ but the descent of modular rhodopsins is not yet known. As this is the first report of modular rhodopsin from diverse organisms; it is noteworthy to analyze the evolutionary pattern of these rhodopsins from different taxa of life.

FimV, UL36, and MED15 coupled Channelrhodopsins (KnRh3, GpRh1, and TsRh1) were grouped with ChR and VChR (Figure 4) while rhodopsins from proteobacterium, proton pumping BR, chloride pumping HR and SR clustered in separate clades (Figure 4). Interestingly, AsRh4 preceded by Rav1 and WD40 domain at $\mathrm{N}$-terminus was the only modular rhodopsin grouped with algal proton pump CsR from Chlorella subellipsoedea. Sequence alignment also confirmed the presence of important residues required for pump activity in AsRh4 (Figures 2 and 3, see text). Surprisingly, modular rhodopsins clustered together independently of SRs. A closer analysis of the branching pattern showed that the ChRs grouped with the modular rhodopsins more closely than the proton pumping algal rhodopsins revealing their unique functional properties. Among the ChRs, the best-characterized one is the light-driven ion channel. The spectroscopically characterized modular rhodopsin domain, Cop5, is a UV and blue light-absorbing rhodopsin [32,38,39]. Cop6 expressed in Xenopus laevis behaves as a light-inhibited guanylate cyclase in the presence of ATP [33]. The photophysical properties of histidine kinase rhodopsin Ot-HKR (referred here as OtRh1) from O. tauri are affected by salt concentration indicating that this rhodopsin might be involved during adaptation in the salt environment [34]. OtHKR/OtRh1 speculated to regulate the circadian clock genes TOC1 and CCA shows a higher expression during dusk [34]. The characterization of additional multidomain rhodopsins is tempting because it may unearth entirely new classes of rhodopsins not known yet. At the same time, it is limiting because of long transcript and high molecular weight protein, poor heterologous expression of the full length and transmembrane domain, and the lack of established functional assays. 


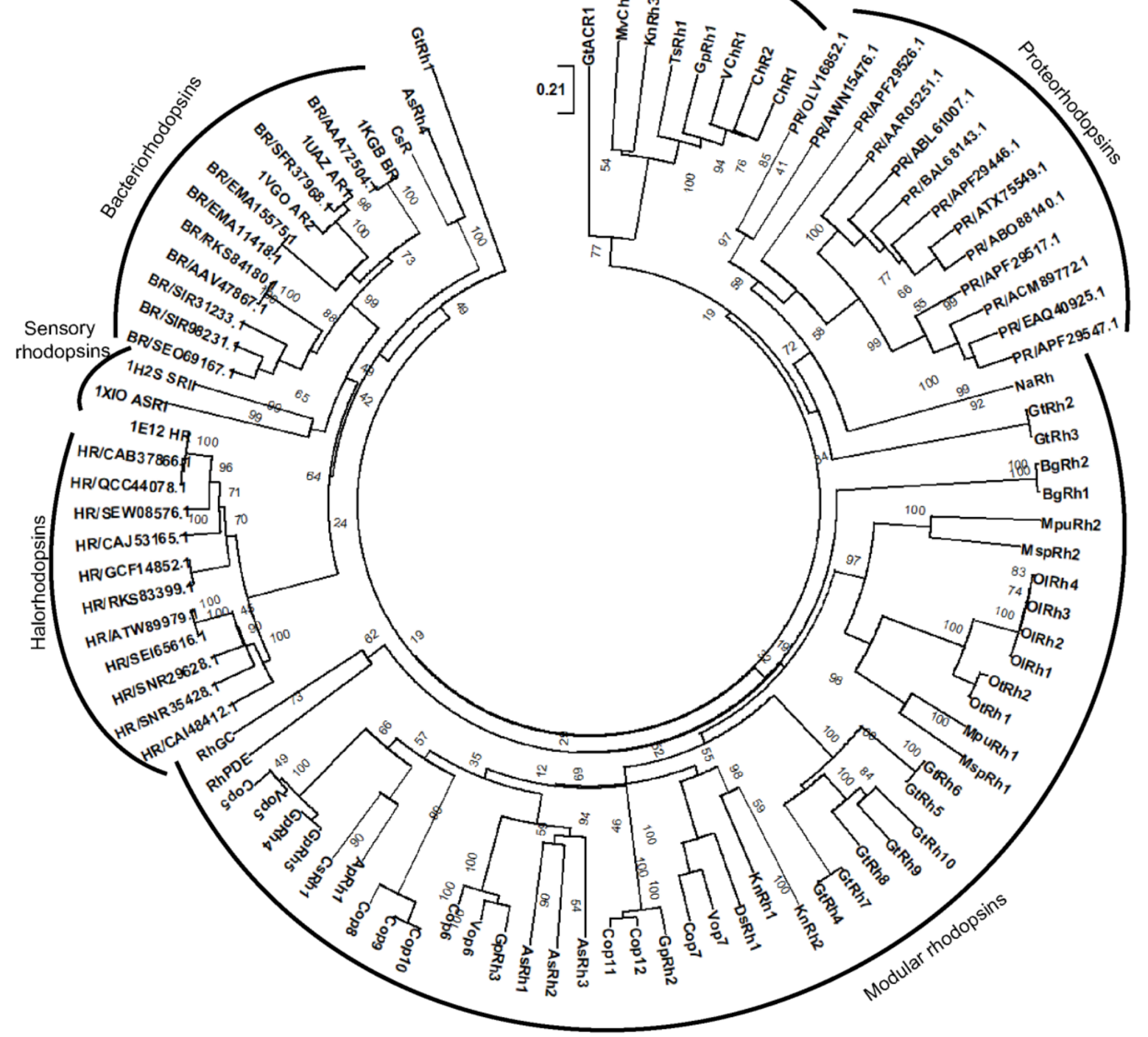

Figure 4. Sequence relatedness of the microbial type modular rhodopsin: Rhodopsin domain phyletic topology shows clustering of typical MTR and extended C-terminus rhodopsins in a separate clade. Modular rhodopsins formed a different clade. KnRh3, GpRh1 and TsRh1 grouped with ChRs. AsRh4 with Rav1 domain is the only modular rhodopsin grouped with proton pumping algal rhodopsin CsR (Rhodopsin from Coccomyxa subllipsodea). GtRh1 was unique and separated from all lying between BR and HR.

\subsection{Cyclase Domain is a Canonical Secondary Messenger of Modular Sensory Type Rhodopsin}

Cyclases are a lyase class of enzymes that catalyze the formation of cyclic nucleotides. Cyclic nucleotide monophosphate (cNMP) serves as a signaling molecule in many prokaryotes and eukaryotes. Based on the substrate specificity, there are two classes of cyclases-adenylyl cyclase (AC) and guanylyl cyclase (GC). Multidomain cyclases are generally composed of a receptor domain at the $\mathrm{N}$-terminus and a cyclase domain at the C-terminus with a kinase homology domain in the center. A similar architecture is found in modular rhodopsin coupled cyclases. Sequence analysis suggests that most cyclase domains have a conserved amino acid residue to perform the enzymatic activity. Cop5 and Vop5 lack the conserved aspartate involved in metal binding (Figure 5). Substrate binding and transition state stabilizing residues are also absent in Cop5 and Vop5 (Figure 5). This points towards an inactive cyclase, 
which was also confirmed by the SMART domain analysis program. Cyclases generally function in the dimer state with the active sites being located at the dimer interface. The activity requires a divalent cation, either $\mathrm{Mg}^{2+}$ or $\mathrm{Mn}^{2+}$. The conserved motifs, especially the transition state stabilizing residues of the cyclase are also missing, which suggests that other transition state stabilizing molecules might be involved in signaling (Figure 5). Both monomers work in tandem to carry out cyclase activity where one determines substrate specificity whereas metal-binding sites are provided by the other monomer. The inactive cyclase might form regulation and another functionally active monomeric partner may complement the activity of the cyclase.

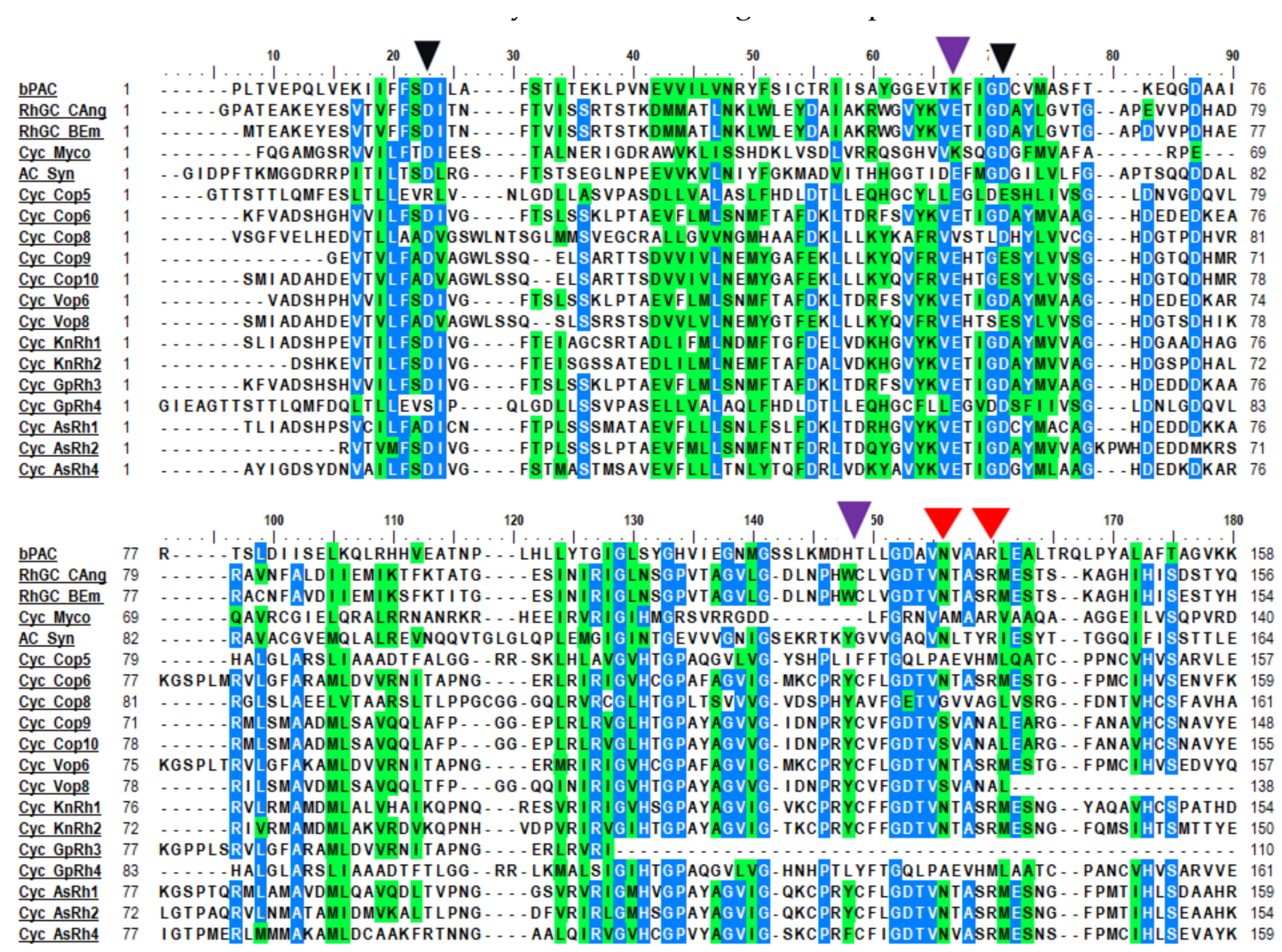

Figure 5. Multiple sequence alignment of the cyclase domain of modular rhodopsins: Cyclase domains of modular rhodopsins were aligned with canonical cyclase proteins. Black arrowhead depicts metal-binding residue, purple arrowhead shows substrate-binding residue and the red arrowhead shows transition state stabilizing the residues of the cyclases.

In C. reinhardtii, cAMP induces the rapid mobilization of membrane adhesion receptor protein from the cell membrane to the ciliary membrane in gametes [27] which leads to the adhesion and fusion of gametes to form the zygote and hence, promotes its sexual life cycle [50]. In the phototaxis mutant strain of $C$. reinhardtii, cyclase activity biases the photo-behavioral response and carotenoid biosynthesis [51]. The modular rhodopsins in conjunction with the two-component system and cyclase might be performing diverse light-regulated physiological functions in the green alga. Sequence analysis suggests degenerate cyclase in Cop5 and Vop5. Apart from the ciliary signaling, cilia beating pattern, phototaxis, and communication with eyespot, some modular rhodopsin(s) must have a diverse physiological role and be localized to a different place than the eyespot [7]. These above-mentioned hypotheses get strong support from the fact that homologous modular rhodopsins are also present in the non-flagellated, eyespot devoid, unicellular green algae Ostreococcus lucimarinus, symbiotic algae, and in colonial algae Volvox carteri. The rhodopsin coupled guanylyl cyclase from the fungus Blastocladiella emersonii was required for the phototactic behavior of the zoospore and had shown in vitro functional activity as well [52]. Rho-GC from other fungi showed promising results in modulating light-dependent 
cGMP levels in Xenopus oocytes, hippocampal neural cells, and Chinese hamster ovary cells [12,13]. It will be interesting to investigate the functional modulation of cAMP/cGMP in the cell by the modular algal rhodopsins as well.

\subsection{Optogenetic Potential of the Novel Modular Rhodopsins}

Among a variety of effector domains coupled with the ChRs, we selected the FimV, MED15, and UL36 domains of functional importance, which have not yet been characterized in the algal system. We subjected these domains to protein-protein interaction network analysis and identified their potential partners and associated pathways. The protein-protein interaction analysis for the FimV domain revealed its association in regulating bacterial pathogenesis machinery (Figure S1A). In the opportunistic pathogen Pseudomonas aeruginosa, FimV is an inner membrane hub protein that controls the type IV pilus (T4P)-mediated twitching motility by regulating the intracellular cAMP level via activation of the adenylate cyclase $\mathrm{CyaB}[53,54]$. Factors like pili, flagella, toxin, etc., that determine the virulence/pathogenicity of microbes are controlled by cAMP, an allosteric activator of the virulence factor regulator, Vfr [55]. However, FimV and the Chp system (PilG, PilJ, PilN, and PilF) also regulate the twitching motility in a cAMP-independent manner in P. aeruginosa, where PilG may regulate the directional movement, while FimV functions to localize both structural and regulatory elements to the cell poles for an optimal function [54]. Therefore, based on the protein network analysis, we propose that the ChR coupled FimV domain could be used for the optogenetic control of cAMP-dependent as well as independent pathways to regulate twitching motility that may elucidate the molecular signaling pathways of pathogen invasion (Figure S3A).

MED15 (co-activator) plays a crucial role in the transcriptional regulation of RNA polymerase II-dependent genes [56]. The protein-protein interaction analysis of the MED15 domain showed that it interacted with other mediator complex subunits (Figure S1B). MED15 was identified as the regulator of mammalian sterol regulatory element-binding protein $1 \alpha$ (SREBP1 $\alpha)$ which controls the genes involved in cellular cholesterol and lipid homeostasis [57]. MED15 possesses a conserve "KIX fold" and is responsible for binding to SREBP1 $\alpha$. This fold is also conserved in the Caenorhabditis elegans orthologue, MDT15, and yeast orthologue GAL11p [57,58]. It has also been reported that the deregulation of the MED15 expression promotes human malignancies and inactivation of MED15 may inhibit the progression of several types of cancers [56,59]. Several studies found that MED15 is an important prognostic biomarker for patients with various types of carcinomas [56,59]. In breast cancer and few epithelial cancers, the inactivation of MED15 inhibits the aberrant transforming growth factor $\beta$ (TGF $\beta$ ) -induced epithelial-mesen chymal transition (EMT), as it acts as a crucial cofactor for TGF $\beta$ signaling [60]. The localized tumor-specific expression of ChR coupled MED15 could be used to target tumor cell signaling and eventually induce the tumor for autophagy or growth arrest in conjunction with other engineered proteins, in a light-dependent manner. Figure S3B represents a probable model for ChR coupled MED15 mediated optogenetic regulation of promoter initiation complex (PIC) assembly (a crucial step in transcriptional regulation), the dysregulation of which leads to oncogenic proliferation.

The UL36 domain, associated with modular ChR, GpRh1 from G. pectorale is a tegument viral protein found in herpes simplex virus 1 (HSV-1) and its homologs are well distributed across the members of Herpes viridae [61]. UL36 protein is an ubiquitin-specific protease [62] which is also evident from our protein-protein interaction analysis of UL36 protein (Figure S2A). Most of the interacting partners like Ubiquitin, 26S proteasome regulatory subunit S5A, proteasome regulatory particle subunit (RpnC), and DSS1/SEM1 family protein belongs to the ubiquitin-dependent proteolysis machinery [63-65]. Proteasome subunit S5a (the human homolog of Rpn10) functions in conjunction with hHR23a/b (the two human homologs of Rad23) to recruit ubiquitylated substrates to the proteasome for their degradation [66]. In humans, DSS1/SEM1 is related to a tumor suppressor protein (BRCA2), which has a crucial role in the recombinational DNA repair in association with RAD51 [67,68]. UL36 deubiquitinating activity has a role in inhibiting the interferon-mediated immune defense upon 
viral invasion in the host [62]. Interestingly, the UL36 domain coupled to GpRh1 showed similarity to the C-terminal segment of HSV-1 UL36 protein (Figure S2B). Böttcher et al. (2005), in a mutation analysis with UL36 homologs from Pseudorabies virus, constructed several truncations and showed that the extreme C-terminus of UL36 having proline/alanine-rich region, is crucial for viral replication [69]. In the proposed model ChR coupled UL36 (C-terminal segment), could be used to regulate capsid assembly, retrograde transport of capsid, entry of viral DNA into the nucleus of the infected host cell as well as nuclear egress (Prototypic Vesicular Nucleo cytoplasmic Transport) in a light-dependent manner (Figure S3C). Based on protein-protein interaction analysis, it may be assumed that ChR coupled effector domains can be utilized as the next generation optogenetic tools, which might help in controlling processes ranging from lipid metabolism, ubiquitin-mediating proteolysis, and pathogenesis to carcinogenesis. Apart from the natural variant, the modular rhodopsins could also be genetically engineered for enhanced kinetics, better spectral tuning (red-shifted spectral compatibility), and modulation to precisely control diverse cellular physiological responses. Hence, the computational analysis of the identified rhodopsins provides an insight into their functionality and further experimental characterization would expand the existing optogenetic toolkit.

\section{Conclusions}

In this study, we have reported various rhodopsins with diverse effector domains. Based on multiple protein sequence alignments and phylogenetic analysis, these modular rhodopsins can be categorized as ChRs, ion pumping (AsRh4), or sensory-type rhodopsins. Owing to the diverse functions offered by the encoded effector domains of these modular rhodopsins hold great potential to expand the optogenetic toolkit. We have also proposed the working models of the modular channelrhodopsins (i.e., ChR-FimV, ChR-MED15, and ChR-UL36), in regulating processes ranging from bacterial pathogenesis, transcription to viral replication and light-gated proteasomal regulation, respectively. The established methods for expression and delivery system could be systematically utilized to design further experiments to study the modular rhodopsin mediated optogenetic modulation of crucial processes across the biological systems. These naturally occurring light-sensitive rhodopsin modules could be recruited in the biological systems and activated relevant approaches such as forced conformational change, heterodimerization, etc. These conformational changes could bring desired changes in cellular signaling like gene expression, protein translocation, and receptor signaling pathways. Empirical optimization, targeted engineering, and directed evolution of the modular rhodopsin(s) would enable us to refine light-sensing mechanisms (e.g., development of red/near infra-red shifted spectral tuning of the rhodopsin) and engineering of the coupled effector domain(s) for extensive applications avenues in optogenetics.

Supplementary Materials: The following are available online at http://www.mdpi.com/2075-1729/10/11/259/s1, Figure S1: Protein-Protein interaction network showing interacting partners of (A) FimV and (B) mediator complex subunit 15 (MED15) domains of modular ChRs. Figure S2: Interactome and sequence alignment of UL36 domain of modular ChR (GpRh1). Figure S3: Schematics representing optogenetic potentials of the modular ChRs. Table S1: Sequence identity of modular rhodopsin used in the analysis and their protein sequences.

Author Contributions: Conceptualization, P.R., M.A. and S.K.; methodology, software, validation, M.A., K.S., M.S.K. and P.R.; writing—original draft preparation, P.R., M.A. and S.K.; writing-review and editing, M.A., K.S., M.S.K., P.R. and S.K.; supervision, P.R. and S.K.; project administration, S.K.; funding acquisition, S.K. All authors have read and agreed to the published version of the manuscript.

Funding: KS fellowship was supported by the Dept. of Biotechnology, India. MSK is financially supported by UGC-DSKPDF, India. DBT, Government of India (BT/010/IYBA/2016) is highly acknowledged for the support of research grants to SK.

Acknowledgments: William J. Snell (University of Maryland College Park, USA) is highly acknowledged for the scientific discussion of the manuscript. Dr. Adivitiya, School of Biotechnology, (Jawaharlal Nehru University, India) is kindly acknowledged for editing of the manuscript. Authors acknowledge National Library of Medicine (NLM), Joint Genome Institute (JGI) portal and Klebsormidium nitens NIES-2285 genome project as a source of sequences used in this study.

Conflicts of Interest: All authors declare no conflicts of interest. 


$\begin{array}{ll}\begin{array}{l}\text { Abbreviations } \\ \text { Cop-Chlamyopsin } \\ \text { Vop-Volvoxopsin }\end{array} & \begin{array}{l}\text { rhodopsin from Chlamydomonas reinhardtii } \\ \text { rhodopsin from Volvox carteri } \\ \text { GpRh 1-5 }\end{array} \\ \text { AsRh1-4 } & \text { Asterochloris sp. } \\ \text { KnRh1-3 } & \text { Klebsormidium nitens } \\ \text { OtRh1-2 } & \text { Ostreococcus tauri } \\ \text { MpuRh1\&2 } & \text { Micromonas pusilla } \\ \text { MspRh1\&2 } & \text { Micromonas species } \\ \text { OlRh1-4 } & \text { Ostreococcus lucimarinus } \\ \text { CsRh1 } & \text { Chlorella sorokiniana } \\ \text { ApRh1 } & \text { Auxenochlorella protothecoides } \\ \text { BgRh1\&2 } & \text { Bigelowiella natans } \\ \text { GtRh1-10 } & \text { Guillardia theta } \\ \text { DsRh1 } & \text { Dunaliella salina } \\ \text { TsRh1 } & \text { Tetraselmis subcordiformis }\end{array}$

\section{References}

1. Oesterhelt, D.; Stoeckenius, W. Functions of a new photoreceptor membrane. Proc. Natl. Acad. Sci. USA 1973, 70, 2853-2857. [CrossRef] [PubMed]

2. Schobert, B.; Lanyi, J.K. Halorhodopsin is a light-driven chloride pump. J. Biol. Chem. 1982, 257, 10306-10313. [PubMed]

3. Nagel, G.; Ollig, D.; Fuhrmann, M.; Kateriya, S.; Musti, A.M.; Bamberg, E.; Hegemann, P. Channelrhodopsin-1: A light-gated proton channel in green algae. Science 2002, 296, 2395-2398. [CrossRef] [PubMed]

4. Nagel, G.; Szellas, T.; Huhn, W.; Kateriya, S.; Adeishvili, N.; Berthold, P.; Ollig, D.; Hegemann, P.; Bamberg, E. Channelrhodopsin-2: A directly light-gated cation-selective membrane channel. Proc. Natl. Acad. Sci. USA 2003, 100, 13940-13945. [CrossRef]

5. Hoff, W.D.; Jung, K.-H.; Spudich, J.L. Molecular mechanism of photosignaling by archaeal sensory rhodopsins. Annu. Rev. Biophys. Biomol. Struct. 1997, 26, 223-258. [CrossRef]

6. Nakagawa, M.; Iwasa, T.; Kikkawa, S.; Tsuda, M.; Ebrey, T.G. How vertebrate and invertebrate visual pigments differ in their mechanism of photoactivation. Proc. Natl. Acad. Sci. USA 1999, 96, 6189-6192. [CrossRef]

7. Awasthi, M.; Ranjan, P.; Sharma, K.; Veetil, S.K.; Kateriya, S. The trafficking of bacterial type rhodopsins into the Chlamydomonas eyespot and flagella is IFT mediated. Sci. Rep. 2016, 6, 34646. [CrossRef]

8. Zhang, F.; Vierock, J.; Yizhar, O.; Fenno, L.E.; Tsunoda, S.; Kianianmomeni, A.; Prigge, M.; Berndt, A.; Cushman, J.C.; Polle, J.; et al. The microbial opsin family of optogenetic tools. Cell 2011, 147, 1446-1457. [CrossRef]

9. Yoshida, K.; Tsunoda, S.; Brown, L.S.; Kandori, H. A unique choanoflagellate enzyme rhodopsin exhibits light-dependent cyclic nucleotide phosphodiesterase activity. J. Biol. Chem. 2017, 292, 7531-7541. [CrossRef]

10. Tian, Y.; Gao, S.; Yang, S.; Nagel, G. A novel rhodopsin phosphodiesterase from Salpingoeca rosetta shows light-enhanced substrate affinity. Biochem. J. 2018, 475, 1121-1128. [CrossRef]

11. Lamarche, L.B.; Kumar, R.P.; Trieu, M.M.; Devine, E.L.; Cohen-Abeles, L.E.; Theobald, D.L.; Oprian, D.D. Purification and characterization of RhoPDE, a retinylidene/phosphodiesterase fusion protein and potential optogenetic tool from the choanoflagellate salpingoeca rosetta. Biochemistry 2017, 56, 5812-5822. [CrossRef] [PubMed]

12. Scheib, U.; Stehfest, K.; Gee, C.E.; Körschen, H.G.; Fudim, R.; Oertner, T.G.; Hegemann, P. The rhodopsin-guanylyl cyclase of the aquatic fungus Blastocladiella emersonii enables fast optical control of cGMP signaling. Optogenetics 2015, 8, rs8.

13. Scheib, U.; Broser, M.; Constantin, O.M.; Yang, S.; Gao, S.; Mukherjee, S.; Stehfest, K.; Nagel, G.; Gee, C.E.; Ehegemann, P. Rhodopsin-cyclases for photocontrol of cGMP/cAMP and $2.3 \AA$ structure of the adenylyl cyclase domain. Nat. Commun. 2018, 9, 2046. [CrossRef] [PubMed]

14. Butryn, A.; Raza, H.; Rada, H.; Moraes, I.; Owens, R.J.; Orville, A.M. Molecular basis for GTP recognition by light-activated guanylate cyclase Rh GC. FEBS J. 2019. [CrossRef] [PubMed] 
15. Trieu, M.M.; Devine, E.L.; Lamarche, L.B.; Ammerman, A.E.; Greco, J.A.; Birge, R.R.; Theobald, D.L.; Oprian, D.D. Expression, purification, and spectral tuning of RhoGC, a retinylidene/guanylyl cyclase fusion protein and optogenetics tool from the aquatic fungus Blastocladiella emersonii. J. Biol. Chem. 2017, 292, 10379-10389. [CrossRef]

16. Bergs, A.; Schultheis, C.; Fischer, E.; Tsunoda, S.P.; Erbguth, K.; Husson, S.J.; Govorunova, E.G.; Spudich, J.L.; Nagel, G.; Gottschalk, A.; et al. Rhodopsin optogenetic toolbox v2.0 for light-sensitive excitation and inhibition in Caenorhabditis elegans. PLoS ONE 2018, 13, e0191802. [CrossRef]

17. Mukherjee, S.; Hegemann, P.; Broser, M. Enzymerhodopsins: Novel photoregulated catalysts for optogenetics. Curr. Opin. Struct. Biol. 2019, 57, 118-126. [CrossRef]

18. Greiner, A.; Kelterborn, S.; Evers, H.; Kreimer, G.; Sizova, I.; Hegemann, P. Targeting of photoreceptor genes in chlamydomonas reinhardtii via zinc-finger nucleases and CRISPR/Cas9. Plant Cell 2017, 29, 2498-2518. [CrossRef]

19. Thompson, J.D. The CLUSTAL_X windows interface: Flexible strategies for multiple sequence alignment aided by quality analysis tools. Nucleic Acids Res. 1997, 25, 4876-4882. [CrossRef]

20. Geer, L.Y.; Domrachev, M.; Lipman, D.J.; Bryant, S.H. CDART: Protein homology by domain architecture. Genome Res. 2002, 12, 1619-1623. [CrossRef]

21. Marchler-Bauer, A.; Bo, Y.; Han, L.; He, J.; Lanczycki, C.J.; Lu, S.; Chitsaz, F.; Derbyshire, M.K.; Geer, R.C.; Gonzales, N.R.; et al. CDD/SPARCLE: Functional classification of proteins via subfamily domain architectures. Nucleic Acids Res. 2016, 45, D200-D203. [CrossRef] [PubMed]

22. Tamura, K.; Peterson, N.; Stecher, G.; Nei, M.; Kumar, S. MEGA5: Molecular evolutionary genetics analysis using maximum likelihood, evolutionary distance, and maximum parsimony methods. Mol. Biol. Evol. 2011, 28, 2731-2739. [CrossRef]

23. Perrière, G.; Gouy, M. WWW-query: An on-line retrieval system for biological sequence banks. Biochimie 1996, 78, 364-369. [CrossRef]

24. Szklarczyk, D.; Morris, J.H.; Cook, H.; Kuhn, M.; Wyder, S.; Simonovic, M.; Santos, A.; Doncheva, N.T.; Roth, A.; Bork, P.; et al. The STRING database in 2017: Quality-controlled protein-protein association networks, made broadly accessible. Nucleic Acids Res. 2016, 45, D362-D368. [CrossRef]

25. Shannon, P.; Markiel, A.; Ozier, O.; Baliga, N.S.; Wang, J.T.; Ramage, D.; Amin, N.; Schwikowski, B.; Ideker, T. Cytoscape: A software environment for integrated models of biomolecular interaction networks. Genome Res. 2003, 13, 2498-2504. [CrossRef] [PubMed]

26. Salomé, P.A.; Merchant, S.S. A series of fortunate events: Introducing chlamydomonas as a reference organism. Plant Cell 2019, 31, 1682-1707. [CrossRef]

27. Ranjan, P.; Awasthi, M.; Snell, W.J. Transient internalization and microtubule-dependent trafficking of a ciliary signaling receptor from the plasma membrane to the cilium. Curr. Biol. 2019, 29, 2942-2947. [CrossRef]

28. Govorunova, E.G.; Sineshchekov, O.A.; Li, H.; Janz, R.; Spudich, J.L. Characterization of a highly efficient blue-shifted channelrhodopsin from the marine alga platymonas subcordiformis. J. Biol. Chem. 2013, 288, 29911-29922. [CrossRef]

29. Volkov, O.; Kovalev, K.; Polovinkin, V.; Borshchevskiy, V.; Bamann, C.; Astashkin, R.; Marin, E.; Popov, A.; Balandin, T.; Willbold, D.; et al. Structural insights into ion conduction by channelrhodopsin 2. Science 2017, 358, eaan8862. [CrossRef]

30. Nack, M.; Radu, I.; Gossing, M.; Bamann, C.; Bamberg, E.; Von Mollard, G.F.; Heberle, J. The DC gate in Channelrhodopsin-2: Crucial hydrogen bonding interaction between C128 and D156. Photochem. Photobiol. Sci. 2010, 9, 194-198. [CrossRef]

31. Stehfest, K.; Ritter, E.; Berndt, A.; Bartl, F.J.; Hegemann, P. The branched photocycle of the slow-cycling channelrhodopsin-2 Mutant C128T. J. Mol. Biol. 2010, 398, 690-702. [CrossRef]

32. Luck, M.; Mathes, T.; Bruun, S.; Fudim, R.; Hagedorn, R.; Nguyen, T.M.T.; Kateriya, S.; Kennis, J.T.M.; Hildebrandt, P.; Ehegemann, P. A photochromic histidine kinase rhodopsin (HKR1) that is bimodally switched by ultraviolet and blue light. J. Biol. Chem. 2012, 287, 40083-40090. [CrossRef] [PubMed]

33. Tian, Y.; Gao, S.; Von Der Heyde, E.L.; Hallmann, A.; Nagel, G. Two-component cyclase opsins of green algae are ATP-dependent and light-inhibited guanylyl cyclases. BMC Biol. 2018, 16, 1-18. [CrossRef] [PubMed]

34. Luck, M.; Escobar, F.V.; Glass, K.; Sabotke, M.-I.; Hagedorn, R.; Corellou, F.; Siebert, F.; Hildebrandt, P.; Ehegemann, P. Photoreactions of the histidine kinase rhodopsin Ot-HKR from the marine picoalga ostreococcus tauri. Biochemie 2019, 58, 1878-1891. [CrossRef] [PubMed] 
35. Man, D.; Wang, W.; Sabehi, G.; Aravind, L.; Post, A.F.; Massana, R.; Spudich, E.N.; Spudich, J.L.; Béjà, O. Diversification and spectral tuning in marine proteorhodopsins. EMBO J. 2003, 22, 1725-1731. [CrossRef] [PubMed]

36. Shimono, K.; Iwamoto, M.; Sumi, M.; Kamo, N. Effects of three characteristic amino acid residues of pharaonis phoborhodopsin on the absorption maximum. Photochem. Photobiol. 2000, 72, 141-145. [PubMed]

37. Shimono, K.; Ikeura, Y.; Sudo, Y.; Iwamoto, M.; Kamo, N. Environment around the chromophore in pharaonis phoborhodopsin: Mutation analysis of the retinal binding site. Biochim. Biophys. Acta BBA Biomembr. 2001, 1515, 92-100. [CrossRef]

38. Luck, M.; Bruun, S.; Keidel, A.; Ehegemann, P.; Hildebrandt, P. Photochemical chromophore isomerization in histidine kinase rhodopsin HKR1. FEBS Lett. 2015, 589, 1067-1071. [CrossRef]

39. Luck, M.; Ehegemann, P. The two parallel photocycles of the Chlamydomonas sensory photoreceptor histidine kinase rhodopsin 1. J. Plant Physiol. 2017, 217, 77-84. [CrossRef]

40. Ogren, J.I.; Mamaev, S.; Russano, D.; Li, H.; Spudich, J.L.; Rothschild, K.J. Retinal chromophore structure and schiff base interactions in red-shifted channelrhodopsin-1 from chlamydomonas augustae. Biochemie 2014, 53, 3961-3970. [CrossRef]

41. Govorunova, E.G.; Spudich, E.N.; Lane, C.E.; Sineshchekov, O.A.; Spudich, J.L. New channelrhodopsin with a red-shifted spectrum and rapid kinetics from mesostigma viride. mBio 2011, 2, e00115-11. [CrossRef] [PubMed]

42. Zhang, F.; Prigge, M.; Beyrière, F.; Tsunoda, S.P.; Mattis, J.; Yizhar, O.; Hegemann, P.; Deisseroth, K. Red-shifted optogenetic excitation: A tool for fast neural control derived from Volvox carteri. Nat. Neurosci. 2008, 11, 631-633. [CrossRef] [PubMed]

43. Oda, K.; Vierock, J.; Oishi, S.; Rodriguez-Rozada, S.; Taniguchi, R.; Yamashita, K.; Wiegert, J.S.; Nishizawa, T.; Hegemann, P.; Nureki, O. Crystal structure of the red light-activated channelrhodopsin Chrimson. Nat. Commun. 2018, 9, 1-11. [CrossRef] [PubMed]

44. Govorunova, E.G.; Sineshchekov, O.A.; Li, H.; Wang, Y.; Brown, L.S.; Spudich, J.L. RubyACRs, nonalgal anion channelrhodopsins with highly red-shifted absorption. Proc. Natl. Acad. Sci. USA 2020, 117, 22833-22840. [CrossRef] [PubMed]

45. Lin, J.Y.; Knutsen, P.M.; Muller, A.; Kleinfeld, D.; Tsien, R.Y. ReaChR: A red-shifted variant of channelrhodopsin enables deep transcranial optogenetic excitation. Nat. Neurosci. 2013, 16, 1499-1508. [CrossRef]

46. Inoue, K.; Marín, M.D.C.; Tomida, S.; Nakamura, R.; Nakajima, Y.; Olivucci, M.; Kandori, H. Red-shifting mutation of light-driven sodium-pump rhodopsin. Nat. Commun. 2019, 10, 1-11. [CrossRef]

47. Ganapathy, S.; Kratz, S.; Chen, Q.; Hellingwerf, K.J.; De Groot, H.J.M.; Rothschild, K.J.; DeGrip, W.J. Redshifted and near-infrared active analog pigments based upon archaerhodopsin-3. Photochem. Photobiol. 2019, 95, 959-968. [CrossRef]

48. Brown, L.S. Fungal rhodopsins and opsin-related proteins: Eukaryotic homologues of bacteriorhodopsin with unknown functions. Photochem. Photobiol. Sci. 2004, 3, 555-565. [CrossRef]

49. Ruiz-González, M.X.; Marín, I. New insights into the evolutionary history of type 1 rhodopsins. J. Mol. Evol. 2004, 58, 348-358. [CrossRef]

50. Pasquale, S.M.; Goodenough, U.W. Cyclic AMP functions as a primary sexual signal in gametes of Chlamydomonas reinhardtii. J. Cell Biol. 1987, 105, 2279-2292. [CrossRef]

51. Boonyareth, M.; Saranak, J.; Pinthong, D.; Sanvarinda, Y.; Foster, K.W. Roles of cyclic AMP in regulation of phototaxis in Chlamydomonas reinhardtii. Biologia 2009, 64, 1058-1065. [CrossRef]

52. Avelar, G.M.; Schumacher, R.I.; Zaini, P.A.; Leonard, G.; Richards, T.A.; Gomes, S.L. A rhodopsin-guanylyl cyclase gene fusion functions in visual perception in a fungus. Curr. Biol. 2014, 24, 1234-1240. [CrossRef] [PubMed]

53. Buensuceso, R.N.C.; Nguyen, Y.; Zhang, K.; Daniel-Ivad, M.; Sugiman-Marangos, S.N.; Fleetwood, A.D.; Zhulin, I.B.; Junop, M.S.; Howell, P.L.; Burrows, L.L. The conserved tetracopeptide repeat-containing C-terminal domain of Pseudomonas aeruginosa FimV is required for its cyclic AMP-dependent and -independent Functions. J. Bacteriol. 2016, 198, 2263-2274. [CrossRef] [PubMed]

54. Buensuceso, R.N.C.; Daniel-Ivad, M.; Kilmury, S.L.N.; Leighton, T.L.; Harvey, H.; Howell, P.L.; Burrows, L.L. Cyclic AMP-independent control of twitching motility in pseudomonas aeruginosa. J. Bacteriol. 2017, 199, 00188-17. [CrossRef] [PubMed] 
55. Berry, A.; Han, K.; Trouillon, J.; Robert-Genthon, M.; Ragno, M.; Lory, S.; Attree, I.; Elsen, S. cAMP and Vfr control exolysin expression and cytotoxicity of pseudomonas aeruginosa taxonomic outliers. J. Bacteriol. 2018, 200, e00135-18. [CrossRef]

56. Wang, K.; Duan, C.; Zou, X.; Song, Y.; Li, W.; Xiao, L.; Peng, J.; Yao, L.; Long, Q.; Liu, L. Increased mediator complex subunit 15 expression is associated with poor prognosis in hepatocellular carcinoma. Oncol. Lett. 2018, 15, 4303-4313. [CrossRef]

57. Yang, F.; Vought, B.W.; Satterlee, J.S.; Walker, A.K.; Sun, Z.-Y.J.; Watts, J.L.; Debeaumont, R.; Saito, R.M.; Hyberts, S.G.; Yang, S.; et al. An ARC/Mediator subunit required for SREBP control of cholesterol and lipid homeostasis. Nat. Cell Biol. 2006, 442, 700-704. [CrossRef]

58. Thakur, J.K.; Arthanari, H.; Yang, F.; Chau, K.H.; Wagner, G.; Näär, A.M. Mediator subunit Gal11p/MED15 is required for fatty acid-dependent gene activation by yeast transcription factor Oaf1p. J. Biol. Chem. 2008, 284, 4422-4428. [CrossRef]

59. Syring, I.; Weiten, R.; Schmidt, D.; Steiner, S.; Kristiansen, G. The knockdown of the Mediator complex subunit MED15 restrains urothelial bladder cancer cells' malignancy. Oncol. Lett. 2018, 16, 3013-3021. [CrossRef]

60. Zhao, M.; Yang, X.; Fu, Y.; Wang, H.; Ning, Y.; Yan, J.; Chen, Y.-G.; Wang, G. Mediator MED15 modulates transforming growth factor beta (TGF $\beta$ )/Smad signaling and breast cancer cell metastasis. J. Mol. Cell Biol. 2013, 5, 57-60. [CrossRef]

61. Schlieker, C.; Korbel, G.A.; Kattenhorn, L.M.; Ploegh, H.L. A Deubiquitinating activity is conserved in the large tegument protein of the herpesviridae. J. Virol. 2005, 79, 15582-15585. [CrossRef] [PubMed]

62. Wang, S.; Wang, K.; Li, J.; Zheng, C. Herpes simplex virus 1 ubiquitin-specific protease UL36 inhibits beta interferon production by deubiquitinating TRAF3. J. Virol. 2013, 87, 11851-11860. [CrossRef] [PubMed]

63. Lander, G.C.; Estrin, E.; Matyskiela, M.E.; Bashore, C.; Nogales, E.; Martin, A. Complete subunit architecture of the proteasome regulatory particle. Nat. Cell Biol. 2012, 482, 186-191. [CrossRef] [PubMed]

64. Jossé, L.; Harley, M.E.; Pires, I.M.S.; Hughes, D.A. Fission yeast Dss1 associates with the proteasome and is required for efficient ubiquitin-dependent proteolysis. Biochem. J. 2005, 393, 303-309. [CrossRef]

65. Wang, Q.; Young, P.; Walters, K.J. Structure of S5a bound to monoubiquitin provides a model for polyubiquitin recognition. J. Mol. Biol. 2005, 348, 727-739. [CrossRef]

66. Walters, K.J.; Goh, A.M.; Wang, Q.; Wagner, G.; Howley, P.M. Ubiquitin family proteins and their relationship to the proteasome: A structural perspective. Biochim. Biophys. Acta Bioenerg. 2004, 1695, 73-87. [CrossRef]

67. Venkitaraman, A.R. Cancer susceptibility and the functions of BRCA1 and BRCA2. Cell 2002, 108, 171-182. [CrossRef]

68. Marston, N.J.; Richards, W.J.; Hughes, D.; Bertwistle, D.; Marshall, C.J.; Ashworth, A. Interaction between the product of the breast cancer susceptibility gene BRCA2 and DSS1, a protein functionally conserved from yeast to mammals. Mol. Cell. Biol. 1999, 19, 4633-4642. [CrossRef]

69. Boöttcher, S.; Klupp, B.G.; Granzow, H.; Fuchs, W.; Michael, K.; Mettenleiter, T.C. Identification of a 709-amino-acid internal nonessential region within the essential conserved tegument protein (p)UL36 of pseudorabies virus. J. Virol. 2006, 80, 9910-9915. [CrossRef]

Publisher's Note: MDPI stays neutral with regard to jurisdictional claims in published maps and institutional affiliations.

(C) 2020 by the authors. Licensee MDPI, Basel, Switzerland. This article is an open access article distributed under the terms and conditions of the Creative Commons Attribution (CC BY) license (http://creativecommons.org/licenses/by/4.0/). 